\title{
Cell size reduction induced by inhibition of the mTOR/ S6K-signaling pathway protects Jurkat cells from apoptosis
}

\author{
C Fumarola ${ }^{*, 1}$, S La Monica ${ }^{1}$, RR Alfieri ${ }^{1}$, E Borra $^{1}$ and \\ GG Guidotti ${ }^{1}$ \\ ${ }^{1}$ Department of Experimental Medicine, Division of Molecular Pathology and \\ Immunology. University of Parma, Parma 43100, Italy \\ * Corresponding author: C Fumarola, Department of Experimental Medicine, \\ Division of Molecular Pathology and Immunology, University of Parma, Via \\ Volturno 39, Parma 43100, Italy. Tel: + 39-0521-903762/903741; \\ Fax: + 39-0521-903742; E-mail: claudia.fumarola@unipr.it
}

Received 28.12.04; revised 16.3.05; accepted 11.4.05; published online 20.5.05 Edited by JA Cidlowski

\begin{abstract}
In Jurkat cells, the decreased cell growth rate associated with a long-lasting deactivation of the mammalian target of rapamycin (mTOR)/p70 ribosomal S6 kinase (S6K)-signaling pathway generates a cell population of progressively reduced cellular mass and size. When promoted by rapamycin as prototype inhibitor, the mTOR deactivation-dependent cell size reduction was associated with slowed, but not suppressed, proliferation. Small-size cells were significantly protected from apoptosis induced by Fas/Apo-1 deathreceptor activation (as shown by reduced procaspase cleavage and decreased catalytic activity of relevant caspases) or by stress signals-dependent mitochondrial perturbation (as shown by reduced cleavage of caspase-2, lower dissipation of mitochondrial membrane potential and decreased release of cytochorome $c$ and apoptosis-inducing factor from mitochondria). Protection faded when reactivation of the mTOR/S6K pathway promoted the cell recovery to normal size. These results suggest that cells induced to reduce their mass by the mTOR deactivation-dependent inhibition of cell growth become more resilient to lethal assaults by curbing the cell's suicidal response.

Cell Death and Differentiation (2005) 12, 1344-1357.

doi:10.1038/sj.cdd.4401660; published online 20 May 2005
\end{abstract}

Keywords: cell size; mTOR/S6K pathway; apoptosis; proliferation; rapamycin; leucine

Abbreviations: AIF, apoptosis-inducing factor; Akt, Akt/protein kinase B; CCL-779, sirolimus; CD95, Fas/Apo-1; ET-18-OCH3, ether lipid 1-O-octadecyl-2-O-methyl-rac-glycero-3-phosphocholine; FBS, fetal bovine serum; FRAP, FKBP12-rapamycin associated protein; ${ }^{3} \mathrm{H}-\mathrm{OMG}$, o-methy-D-[1- $\left.{ }^{3} \mathrm{H}\right]$ glucose; HRP, horseradish peroxidase; $\mathrm{G} \beta \mathrm{L}, \mathrm{G}$ protein $\beta$-subunit-like protein; LY294002, 2-(4-morpholinyl)-8-phenyl-4H-1-benzopyran-4-one; mTOR, mammalian target of rapamycin; PI3K, phosphatidylinositol 3-kinase; p-p70S6k, p70 S6K phosphoprotein; RAD001, everolimus; RAFT-1, rapamycin and FKBP12 target; Rheb, Ras-related protein Rheb; SDS-PAGE, sodium, dodecyl sulfate-polyacrylamide gel electrophoresis; Sts, staurosporine; S6K, p70 ribosomal S6 kinase; 5'-TOP, 5'-terminal oligopyrimidine tract; Tsc, tuberous sclerosis complex

\section{Introduction}

An emerging model of cell growth, proliferation and death posits the evolutionarily conserved Ser/Thr protein kinase mammalian target of rapamycin (mTOR) as a central sensor of multiple environmental and metabolic information. ${ }^{1-3}$ In this model, signals arising from the extracellular milieu as growth factors $^{4,5}$ and nutrient availability, ${ }^{6,7}$ from changes of transporter activity at the cell membrane $e^{8,9}$ or directly from intracellular metabolic changes affecting internal amino-acid levels ${ }^{9-13}$ and ATP availability ${ }^{14-16}$ all feed into mTOR which, by integrating this information, couples the cellular metabolic state to downstream targets that modulates rates of translation and thereby cell mass and number. ${ }^{17}$ mTOR, also known as FKBP12-rapamycin-associated protein (FRAP) ${ }^{18} /$ rapamycin and FKBP12 target (RAFT-1) ${ }^{19}$ with its putative raptor, ${ }^{20,21}$ $\mathrm{G}$ protein $\beta$-subunit-like protein $(\mathrm{G} \beta \mathrm{L})^{22}$ and tuberous sclerosis complex (Tsc)/Ras-related protein (Rheb) ${ }^{3,12}$ regulators, modulate the phosphorylation state of p70 ribosomal S6 kinase 1 (S6K1) and other downstream effectors. ${ }^{3,23,24}$ In Drosophila, the loss of function of dS6K, the orthologue of mammalian S6K, is associated with slow overall growth rate and decreased cell size. ${ }^{25-27}$ Similarly in mammals, the deactivation of S6K1 that follows the inhibition of the mTOR kinase by rapamycin treatment, ${ }^{20,28-30}$ by leucine deprivation $^{20}$ or by 2-(4-morpholinyl)-8-phenyl-4H-1-benzopyran-4-one (LY294002)-dependent inhibition of the phosphatidylinositol 3-kinase (PI3K)/Akt/protein kinase $\mathrm{B}(\mathrm{Akt}) /$ mTOR-signaling pathway ${ }^{29}$ is associated with decreased cell growth rate and progressive reduction in cell size, showing that the function of the mTOR-dependent target S6K1 in cell size control is evolutionarily conserved. ${ }^{3}$ The activation of S6K1 is regulated by multisite phosphorylation. ${ }^{4,31,32}$ Four sites have been identified in the autoinhibitory domain of the C-terminus of the S6K1 protein (Ser411, Ser418, Thr421 and Ser424) whose early phosphorylation releases the catalytic domain from the pseudosubstrate and permits subsequent phosphorylation of critical sites, as Thr389, in the linker region. ${ }^{31}$ The mTOR kinase activity is liable to phosphorylate S6K1 at residues Thr421 and Ser424 ${ }^{33}$ (an event that precedes the phosphorylation of Thr389) and phosphorylates directly the Thr389 site $^{31}$ associated with optimal activation of the S6 kinase activity. In vitro, Thr389 is the major rapamycinsensitive site. ${ }^{34}$ However, the phosphorylation state of $\mathrm{S} 6 \mathrm{~K}$ is also controlled by a subordinate protein phosphatase ${ }^{35-38}$ whose activation is indirectly restrained by $\mathrm{mTOR}$ and 
promoted by amino-acid deprivation. ${ }^{38}$ The phosphatase activity affecting the phosphorylation state of downstream targets of mTOR appears to be dependent on its association with the $\alpha 4$ protein, ${ }^{36,37,39}$ an integral component of the rapamycin-sensitive-signaling pathway. ${ }^{1}$ The complex $\alpha 4 /$ phosphatase and its dephosphorylating activity on S6K is disrupted in the presence of phosphatase inhibitors, ${ }^{40,41}$ whereas the effects of rapamycin are controversial. ${ }^{35,36,39,41}$ The decreased cell growth rate and the progressive reduction of cell size accompanying or promoted by S6K1 deactivation that follows the inhibition of the mTOR kinase depress cell proliferation $^{20,29,30,42,43}$ (with wide variations among cell types) by a complex mechanism still poorly understood. Whether these changes in cell growth (and size) affect cell survival by inhibition or promotion of cell death is still controversial and no specific experiments have been addressed to evaluate their proapoptotic or antiapoptotic effects on the different death pathways. We therefore decided to investigate whether conditions that lead to long-lasting mTOR/S6K1 deactivation-dependent decrease of cell size affect proliferation and cell death by caspase-dependent pathways. In our study, we took advantage of the leukemic T-cell line Jurkat (CD95 (Fas/Apo-1) type II cells ${ }^{44}$ ), a valuable model in signal transduction and biochemical investigations ${ }^{45}$ that, being PTEN-deficient, experiences an increased dependency on mTOR-signaling function. ${ }^{30}$ The inhibition of the mTOR kinase/S6K1 pathway was effected by rapamycin as prototype treatment, by LY294002 as inhibitor of the PI3K/Akt/ mTOR pathway or by leucine deprivation. Apoptotic cell death was induced by ligation of cell-surface death receptors or by ligand-independent receptor oligomerization (extrinsic pathway ${ }^{46}$ ) and through perturbation of the mitochondrial membrane by stress agents (intrinsic pathway ${ }^{47,48}$ ).

Here, we report that the reduced cell growth rate induced by persistent deactivation of the mTOR/S6K1-signaling pathway generates a cell population of progressively decreased cellular mass and size, whose proliferation slows down, but is not suppressed. Upon S6K1 rephosphorylation, cells gradually recover their normal size and regain normal proliferation rate. The decreased cell mass and size induced by inhibition of the mTOR/S6K1 pathway is associated with protection from cell death receptor- and mitochondriallymediated apoptosis. The protection fades when reactivation of the pathway promotes cell recovery to normal size. Several steps of the death-signaling pathways, with involvement of initiator and effector caspases, appear to be restrained in small-size cells, perhaps as a result of a perturbation of their plasmatic and mitochondrial membrane properties due to changes in the physical state of the intracellular compartment controlled by a putative sizer network.

\section{Results}

\section{Characterization of the Jurkat cell model: changes in cell mass and energy status associated with deactivation of the mTOR/S6K1 pathway}

In the experiments described in this paper, deactivation of the mTOR/S6K1 pathway and associated changes in cell size (with the succeeding effects on cell proliferation and apoptosis) were induced by the following treatments: (a) rapamycin at $20 \mathrm{nM}$ concentration (but comparable results were obtained with a $10 \mathrm{nM}$ concentration of the drug), (b) LY294002 at a marginally toxic concentration $(30 \mu \mathrm{M})^{49}$ and (c) leucine deprivation as a signal that couples amino-acid shortage to the S6 kinase dephosphorylation. To study the changes in the mass relevant components of cell size and in the energy status of Jurkat cells, we have determined the values of intracellular water volume, cell protein content, cell dry mass and ATP content of the cells incubated under the conditions adopted. In these cells, the size reduction induced by inhibition of the mTOR/S6K1 pathway with rapamycin (used as prototypical inactivator in experiments reported in Table 1) was dependent on the contribution of both water release and decreased cell protein content, with corresponding loss of dry cell mass (20\% loss, mean of three experiments). Conversely, the size recovery that followed the inhibitor removal relayed on cell growth-dependent accumulation of intracellular water and proteins. In our untreated Jurkat cell clone, the water content was approximately $80 \%$ of the total cell mass and therefore the measurement of the intracellular water volume provides an acceptable estimate of the change in cell size. Cytoplasmic ATP concentration in mammalian cells lies in the low millimolar range $\mathrm{e}^{50,51}$ with similar resting intracellular ATP concentration $\left([\mathrm{ATP}]_{\mathrm{i}}\right)$ in the cytosol, in the mitochondrial matrix and in the submembrane domain. ${ }^{50,52}$ The apparent $\mathrm{K}_{\mathrm{m}}$ of mTOR for ATP is slightly greater than $1 \mathrm{mM}$ with saturating activity at 2 or $3 \mathrm{mM} \mathrm{ATP} .{ }^{14}[\mathrm{ATP}]_{\mathrm{i}}$ assessment in cells that undergo changes in size and water content requires a rigorous measurement of these parameters. As shown in Table 1, incubation of Jurkat cells for $24 \mathrm{~h}$ in the presence of the mTOR kinase inhibitor rapamycin was not associated with a significant change in the average ATP cell content, but its intracellular concentration $\left([A T P]_{i}\right)$ increased by about $25 \%$.

\section{The mTOR inhibition-dependent S6K1 dephosphorylation is associated with a progressive decrease in cell size}

In typical experiments, Jurkat cells, seeded at a density of $0.5 \times 10^{6} \mathrm{cells} / \mathrm{ml}$, were incubated up to $96 \mathrm{~h}$ in dialyzed fetal

Table 1 Mass relevant components and energy status of Jurkat cells untreated or subjected to long-lasting mTOR inhibition by rapamycin

\begin{tabular}{lrr}
\hline & Control & Rapamycin 24 h \\
\hline Cell protein content $\left(\mathrm{mg} / 10^{6}\right.$ cells) & $0.139 \pm 0.022$ & $0.107 \pm 0.017$ \\
Cell water volume $\left(\mu \mathrm{l} / 10^{6}\right.$ cells) & $1.097 \pm 0.107$ & $0.793 \pm 0.032$ \\
ATP cell content $\left(\mathrm{nmol} / 10^{6}\right.$ cells) & $2.384 \pm 0.485$ & $2.169 \pm 0.104$ \\
[ATP] $(\mathrm{mM})$ & $2.173 \pm 0.442$ & $2.740 \pm 0.132$ \\
\hline
\end{tabular}

Values are means \pm S.D. of three to five experiments. 
bovine serum (FBS)-supplemented RPMI 1640 (always renewed every $24 \mathrm{~h}$, with cell density restored at the same initial value by a splitting procedure) in the absence (control) or the presence of $20 \mathrm{nM}$ rapamycin (newly added at every medium renewal along the entire incubation period). Figure 1a shows that the phosphorylation state of S6K1 detected in control cells changed to S6K1 dephosphorylation in cells treated with rapamycin for $24 \mathrm{~h}$. In control cells, phosphorylation of S6K1 remained constant along the following incubation period, whereas rapamycin treatment was associated with persistent dephosphorylation of S6K1. The water volume remained constant along the entire incubation period in control cells, while it diminished by about $30 \%$ of its initial value after $24 \mathrm{~h}$ of incubation in rapamycin-treated cells and decreased progressively thereafter (with a $45 \%$ decrease at 72-96h, Figure 1b). Incubations of short duration (4h), in the presence of $20 \mathrm{nM}$ rapamycin, were sufficient to induce dephosphorylation of S6K1 (Figure 1c), but did not change significantly the water volume of Jurkat cells (Figure 1d). To understand whether the effects of the drug on dephosphorylation of S6K1 and on decrease of cell size were reversible, Jurkat cells, seeded at a density of $0.5 \times 10^{6} \mathrm{cells} / \mathrm{ml}$, were incubated for $24 \mathrm{~h}$ in a $20 \mathrm{nM}$ rapamycin-containing medium, transferred into basal medium (always renewed every $24 \mathrm{~h}$, with cell density restored at the same initial value by a splitting procedure) and incubated for an additional $72 \mathrm{~h}$ (with a further final assay at $144 \mathrm{~h}$ of incubation). After rapamycin removal, S6K1 remained dephosphorylated for $24 \mathrm{~h}$ and became progressively rephosphorylated thereafter (Figure 1a, recovery). After rapamycin removal, the cell water volume a
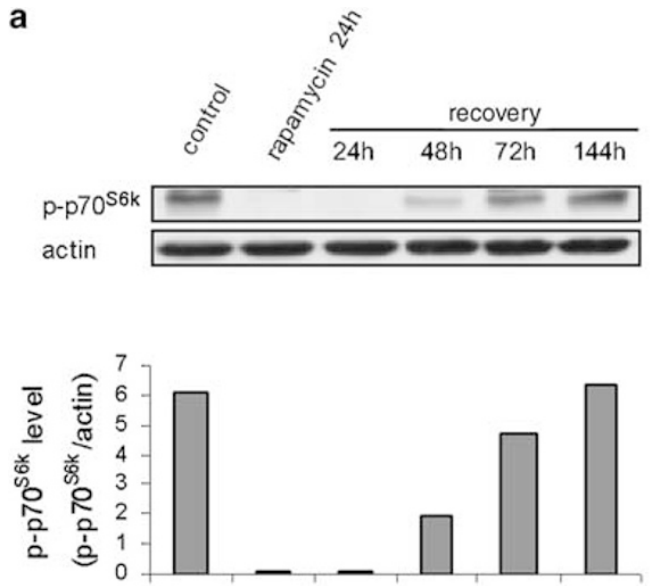

b

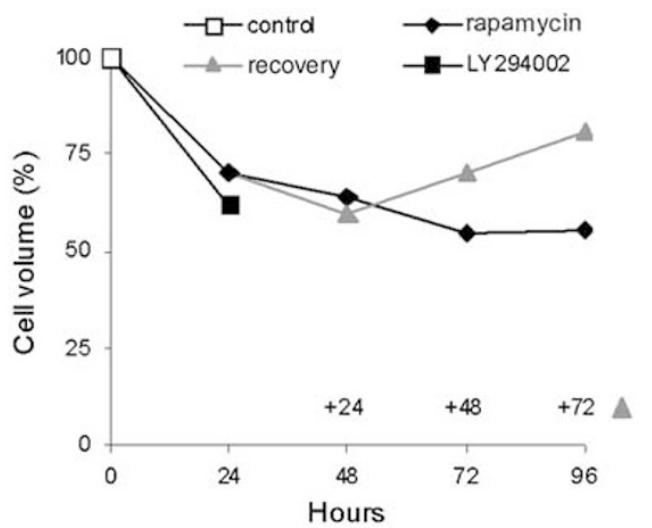

C

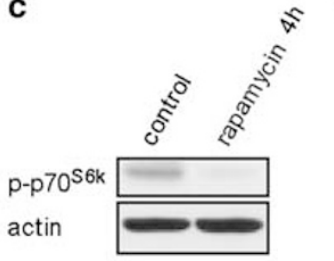

e

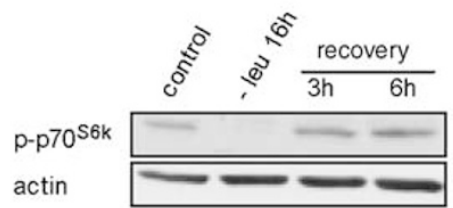

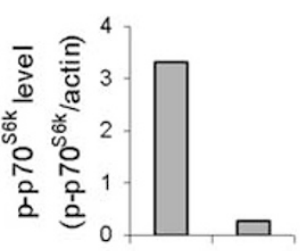

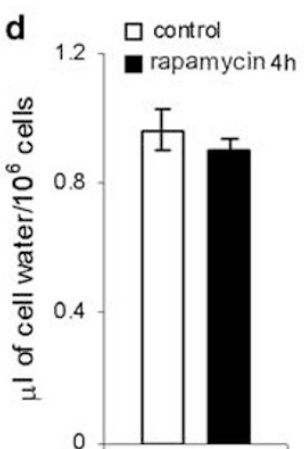

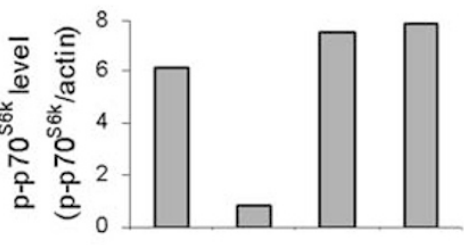

f

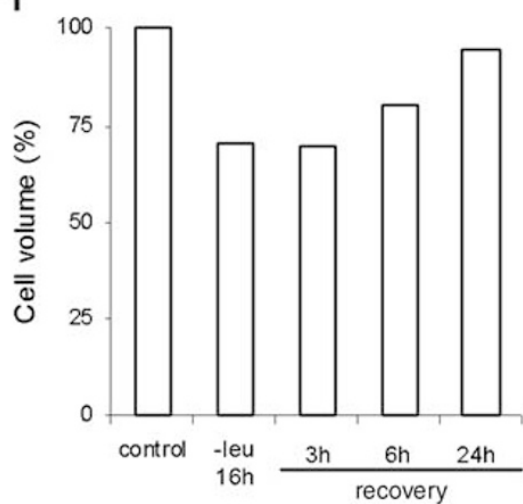

Figure 1 Long-lasting deactivation of the mTOR/S6K1 pathway by rapamycin, LY294002 and leucine deprivation is associated with cell size decrease. (a) Jurkat cells, seeded at a density of $0.5 \times 10^{6} \mathrm{cells} / \mathrm{ml}$, were incubated for $96 \mathrm{~h}$ in dialyzed FBS-supplemented RPMI 1640 (always renewed every $24 \mathrm{~h}$, with cell density restored at the same initial value by a splitting procedure) in the absence (basal medium, control), and the presence of $20 \mathrm{nM}$ rapamycin (newly added at every medium renewal along the entire incubation period) or for $24 \mathrm{~h}$ in the presence of $20 \mathrm{nM}$ rapamycin and then transferred into basal medium (recovery). The recovery was continued up to $144 \mathrm{~h}$. Cell lysates were analyzed by Western blotting using a phosphospecific Thr421/Ser424 anti-p70S6K antibody and an antiactin antibody. The levels of S6K1 phosphoprotein (p-p70S6K), quantitated by densitometric analysis, were normalized to the levels of actin; (b) cells were incubated as in (a) or for $24 \mathrm{~h}$ in the presence of $30 \mu \mathrm{M} \mathrm{LY} 294002$ and cell water volumes were assessed at the indicated time intervals by measurements of the steady-state distribution of ${ }^{3} \mathrm{H}-\mathrm{OMG}$; data, expressed as percent of the control values, are means of three to five experiments. (c and d) Cells were incubated for $4 \mathrm{~h}$ in the absence (control) or the presence of $20 \mathrm{nM}$ rapamycin: S6K phosphorylation was analyzed by Western blotting in cell lysates and quantitated as described in (a) and cell water volumes were assessed by measurements of the steady-state distribution of ${ }^{3} \mathrm{H}-\mathrm{OMG}$; data of cell volume, expressed as microliter of cell water $/ 10^{6}$ cells, are means \pm S.D. of four separate experiments. (e and f) Cells were incubated for $16 \mathrm{~h}$ in the basal medium (control), in a leucine-free medium (-leu) or in leucine-free medium and then transferred into basal medium up to $24 \mathrm{~h}$ (recovery). S6K phosphorylation was analyzed by Western blotting in cell lysates and quantitated as described in (a) and cell water volumes were assessed at the indicated time intervals by measurements of the steady-state distribution of ${ }^{3} \mathrm{H}-\mathrm{OMG}$; data of cell volume, expressed as percent of the control values, are means of three experiments. Western blotting and cell volume measurements were performed on cell populations set free of dead cells by specific column filtration (see Materials and Methods) at the end of the initial $16 \mathrm{~h}$ incubation. Data in a, $\mathbf{c}$ and $\mathbf{e}$ are from a representative experiment. Each experiment, repeated three times, yielded similar results 
decreased further for $24 \mathrm{~h}$ and then increased progressively up to $72 \mathrm{~h}$ (when the average cell water volume was still $80 \%$ of its initial value, Figure $1 \mathrm{~b}$ ). A complete recovery of S6K1 rephosphorylation was observed at $144 \mathrm{~h}$ (Figure 1a, recovery), when total growth-dependent cell mass (intracellular water volume and protein content) attained the same value of control cells. The treatment of Jurkat cells for $24 \mathrm{~h}$ with $30 \mu \mathrm{M}$ LY294002, an inhibitor of the PI3K/mTOR pathway, induced a decrease in cell size even more pronounced than that promoted by $20 \mathrm{nM}$ rapamycin (Figure $1 \mathrm{~b}$ ). Incubations of Jurkat cells in a leucine-free medium, a condition that causes S6K1 dephosphorylation (cf. Fumarola et al. ${ }^{9}$ ) was also associated with a progressive volume decrease of viable cells (cell population set free of dead cells by specific column filtration, see Materials and Methods). After $16 \mathrm{~h}$, the dephosphorylation of S6K1 (Figure 1e) was associated with a reduction of cell volume that approximated $30 \%$ of its initial value (Figure 1f). The population of small-size viable cells was then transferred into a complete medium. Under these conditions, Jurkat cells reactivated the mTOR/S6K pathway within $3 \mathrm{~h}$ (Figure 1e) and recovered their normal size within $24 \mathrm{~h}$ (Figure 1f).

\section{Proliferation rate is slowed, but not suppressed in small-size cells}

Since conditions that promote the decrease in cell size by deactivating the mTOR/S6K pathway (rapamycin treatments, a

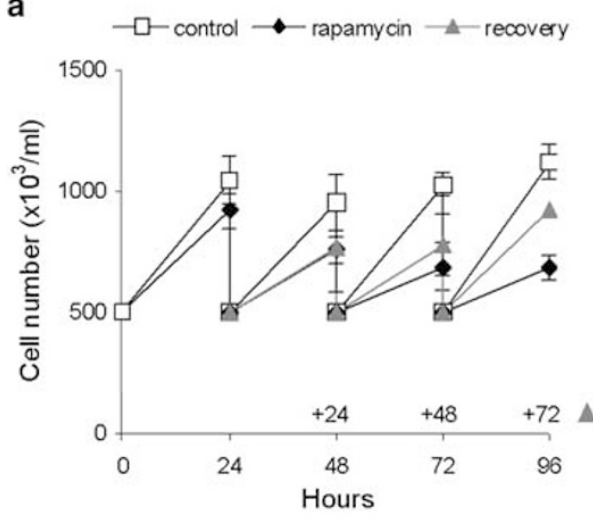

C
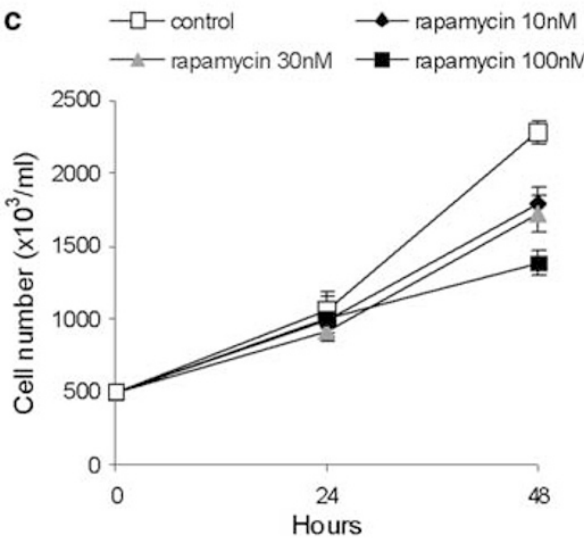
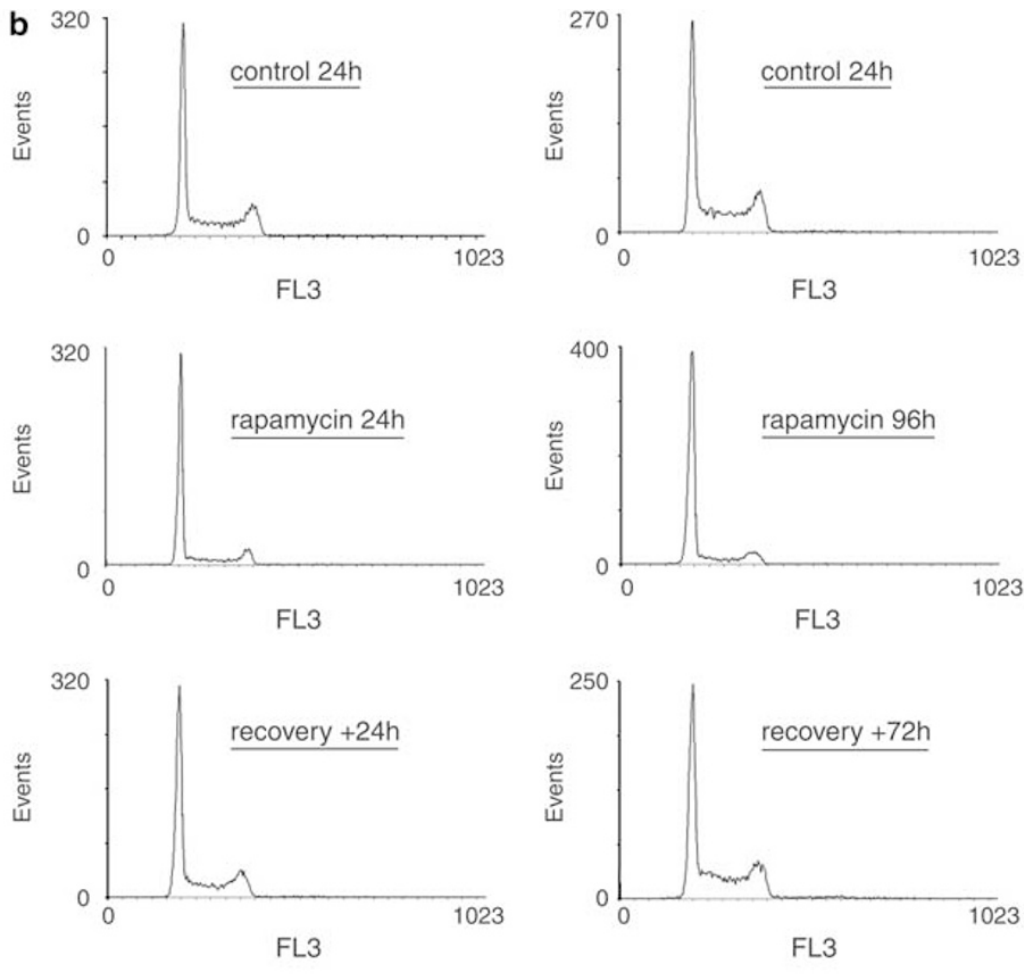

\begin{tabular}{l|ccc|ccc|ccc|c}
\hline \multicolumn{4}{c}{ control } & \multicolumn{3}{c}{ rapamycin } & \multicolumn{4}{c}{ recovery } \\
\hline & $G_{01}$ & $S$ & $G_{2} / M$ & $G_{01}$ & $S$ & $G_{2} / M$ & $G_{0 / 1}$ & $S$ & $G_{2} / M$ & \\
\hline $24 h$ & 49 & 38 & 13 & 69 & 22 & 9 & & & & \\
$48 \mathrm{~h}$ & 48 & 37 & 15 & 76 & 16 & 8 & 57 & 32 & 11 & $+24 \mathrm{~h}$ \\
$72 \mathrm{~h}$ & 48 & 39 & 13 & 75 & 17 & 8 & 55 & 35 & 10 & $+48 \mathrm{~h}$ \\
$96 \mathrm{~h}$ & 44 & 44 & 12 & 77 & 15 & 8 & 45 & 45 & 10 & $+72 \mathrm{~h}$ \\
\hline
\end{tabular}

Figure 2 Rapamycin-dependent reduction in cell size slows down but does not suppress cell proliferation. (a) Jurkat cells, seeded at a density of $0.5 \times 10^{6}$ cells $/ \mathrm{ml}$, were incubated for $96 \mathrm{~h}$ in dialyzed FBS-supplemented RPMI 1640 (always renewed every $24 \mathrm{~h}$, with cell density restored at the same initial value by a splitting procedure) in the absence (basal medium, control), in the presence of $20 \mathrm{nM}$ rapamycin (newly added at every medium renewal along the entire incubation period), or for $24 \mathrm{~h}$ in the presence of $20 \mathrm{nM}$ rapamycin and then transferred into basal medium (recovery). In some experiments, the recovery was continued up to $144 \mathrm{~h}$. Cell proliferation was evaluated by counting the cells in a Bürker hemocytometer and cell viability was assessed by trypan blue exclusion; data are means \pm S.D. of three separate experiments; (b) cells were incubated as described in (a) and, at the indicated time intervals, were stained with propidium iodide and analyzed by flow cytometry for cell-cycle-phase distribution. Cytofluorimetric profiles and percentages of cells residing in each cycle phase (reported below) are from a representative experiment; the experiment, repeated three times, yielded similar results. (c) Cells, seeded at a density of $0.5 \times 10^{6} \mathrm{cells} / \mathrm{ml}$, were incubated for $48 \mathrm{~h}$ in the absence (control) or the presence of 10,30 and $100 \mathrm{nM}$ rapamycin; cell proliferation was evaluated by counting the cells in a Bürker hemocytometer and cell viability was assessed by trypan blue exclusion. Data are means \pm S.D. of three separate experiments 
leucine deprivation) may affect the cell death rate, conditions were selected to assess proliferation on viable cells. The effect of rapamycin on proliferation of Jurkat cells was evaluated by incubating them in FBS-supplemented RPMI 1640 in the absence (control) and the presence of $20 \mathrm{nM}$ rapamycin. When seeded at a density of $0.5 \times 10^{6} \mathrm{cells} / \mathrm{ml}$ and restored at the same initial density by a splitting procedure every $24 \mathrm{~h}$, control cells doubled continually within the intersplit periods for at least $96 \mathrm{~h}$ (Figure 2a). With rapamycin present in the medium, cells gradually decreased their volume (Figure 1b) but proliferation, although progressively reduced (with an increasing number of cells residing in $\mathrm{G}_{1}$ phase, Figure 2b), was not suppressed at a smaller size (Figure 2a). Both control and rapamycin-treated cells did not show
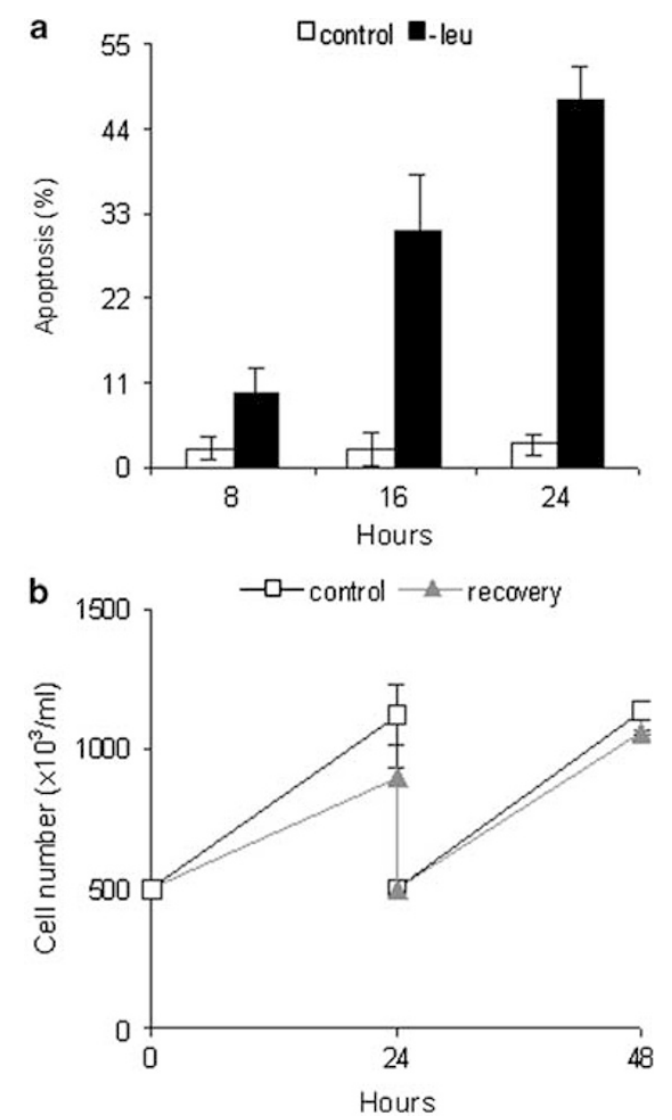

Figure 3 Leucine deprivation arrests proliferation and induces apoptosis, but leucine reinstatement allows viable cells to recover the initial proliferation rate. (a) Jurkat cells were seeded at a density of $0.5 \times 10^{6} \mathrm{cells} / \mathrm{ml}$ in leucine-containing (basal medium, control) or in leucine-free (-leu) RPMI 1640 supplemented with $10 \%$ dialyzed FBS and incubated for $24 \mathrm{~h}$. Apoptosis was quantitated at the indicated time intervals by fluorescence microscopy analysis on Hoechst 33342 and propidium iodide-stained cells. Data, expressed as percent values, are means \pm S.D. of three separate experiments. (b) Cells were incubated for $16 \mathrm{~h}$ in leucine-containing (basal medium, control) or leucine-free medium; at this time, the two cell populations were set free of dead cells by specific column filtration (see Materials and Methods). Viable cells from both populations (control or leucine deprived, from now indicated as recovery) were then transferred into basal medium at a density of $0.5 \times 10^{6} \mathrm{cells} / \mathrm{ml}$ and incubated for an additional $48 \mathrm{~h}$ (with medium renewed at $24 \mathrm{~h}$ and cell density restored at the same initial value by a splitting procedure). Cell proliferation was evaluated by counting the cells in a Bürker hemocytometer and cell viability was assessed by trypan blue exclusion. Data are means \pm S.D. of three separate experiments significant apoptotic response along the entire experimental period. A dose-response with increasing rapamycin concentrations (range: $10-100 \mathrm{nM}$ ) showed that proliferation in cells of reduced size was maintained (although at a decreasing rate) even at the highest concentration of the macrolide (Figure 2c) in the absence of significant apoptotic cell death (cf. Strauss et al. ${ }^{53}$ ). To verify whether the effects of the drug on cell proliferation were reversible, Jurkat cells, seeded at a density of $0.5 \times 10^{6}$ cells $/ \mathrm{ml}$, were incubated for $24 \mathrm{~h}$ in a $20 \mathrm{nM}$ rapamycin-containing medium, transferred into basal medium (always renewed every $24 \mathrm{~h}$, with cell density restored at the same initial value by a splitting procedure) and incubated for an additional $72 \mathrm{~h}$ (with a further final assay at $144 \mathrm{~h}$ of incubation). Cells transferred in rapamycin-free basal medium maintained a slow proliferation rate comparable to that allowed by the rapamycin treatment up to $24 \mathrm{~h}$ and then started to increase their proliferation, reaching an approximate $80 \%$ of the rate of control cells at $72 \mathrm{~h}$ (Figure 2a, recovery). A complete recovery of cell proliferation was observed at $144 \mathrm{~h}$ after rapamycin removal. The cytofluorimetric analysis of cell cycle (Figure $2 \mathrm{~b}$ ) showed that the relative number of cells residing in $\mathrm{G}_{1}$ phase diminished after $24 \mathrm{~h}$ of recovery and reverted to normal values (with an increased number of cells present in $S$ and $G_{2} / M$ ) after $72 \mathrm{~h}$ of incubation, that is earlier than the complete recovery of cell water volume and rate of proliferation. Jurkat cells, seeded at a density of $0.5 \times 10^{6} \mathrm{cells} / \mathrm{ml}$ and incubated in leucine-free medium ceased to divide within 8-10 h. Under these conditions, the size of viable cells decreased gradually and the process was accompanied by an increasing fraction of dead cells that, after $16 \mathrm{~h}$ of leucine deprivation, reached about $30 \%$ of the cell population (Figure $3 a$ ). At this time, the cell population was set free of dead cells by specific column filtration (see Materials and Methods). Viable cells (that had attained a size reduction comparable to that induced by rapamycin treatment, cf. Figure $1 \mathrm{~b}$ and $\mathrm{f}$ ), when transferred into basal medium (renewed at $24 \mathrm{~h}$, with cell density restored at the same initial value by a splitting procedure) resumed proliferation at an increasing rate, reaching values comparable to those of controls after $48 \mathrm{~h}$ (Figure $3 \mathrm{~b}$, recovery). Along the period required to attain a normal proliferation rate, only a few apoptotic events were detected in the cell population.

\section{Small-size cells are protected from apoptosis}

Persistent deactivation of the mTOR/S6K pathway by longlasting rapamycin treatment resulted in small-size cells that resisted apoptosis. As shown in Figure 4a, Jurkat cells whose size was reduced by a $24 \mathrm{~h}$ treatment with $20 \mathrm{nM}$ rapamycin were significantly protected from apoptotic cell death promoted by CD95 receptor-ligation with agonistic anti-CD95 antibodies (extrinsic pathway) or by mitochondrial perturbation (intrinsic pathway) induced through etoposide (a DNAdamaging topoisomerase II inhibitor) or staurosporine (Sts) (a broad spectrum protein kinase inhibitor) treatments. Reduction of cell size promoted by rapamycin treatment also diminished significantly the apoptotic response to the fast cell shrinkage associated with the bulky water release after glutamine deprivation or amino-acid withdrawal (extrinsic pathway, ligand-independent CD95 receptor-mediated apo- 

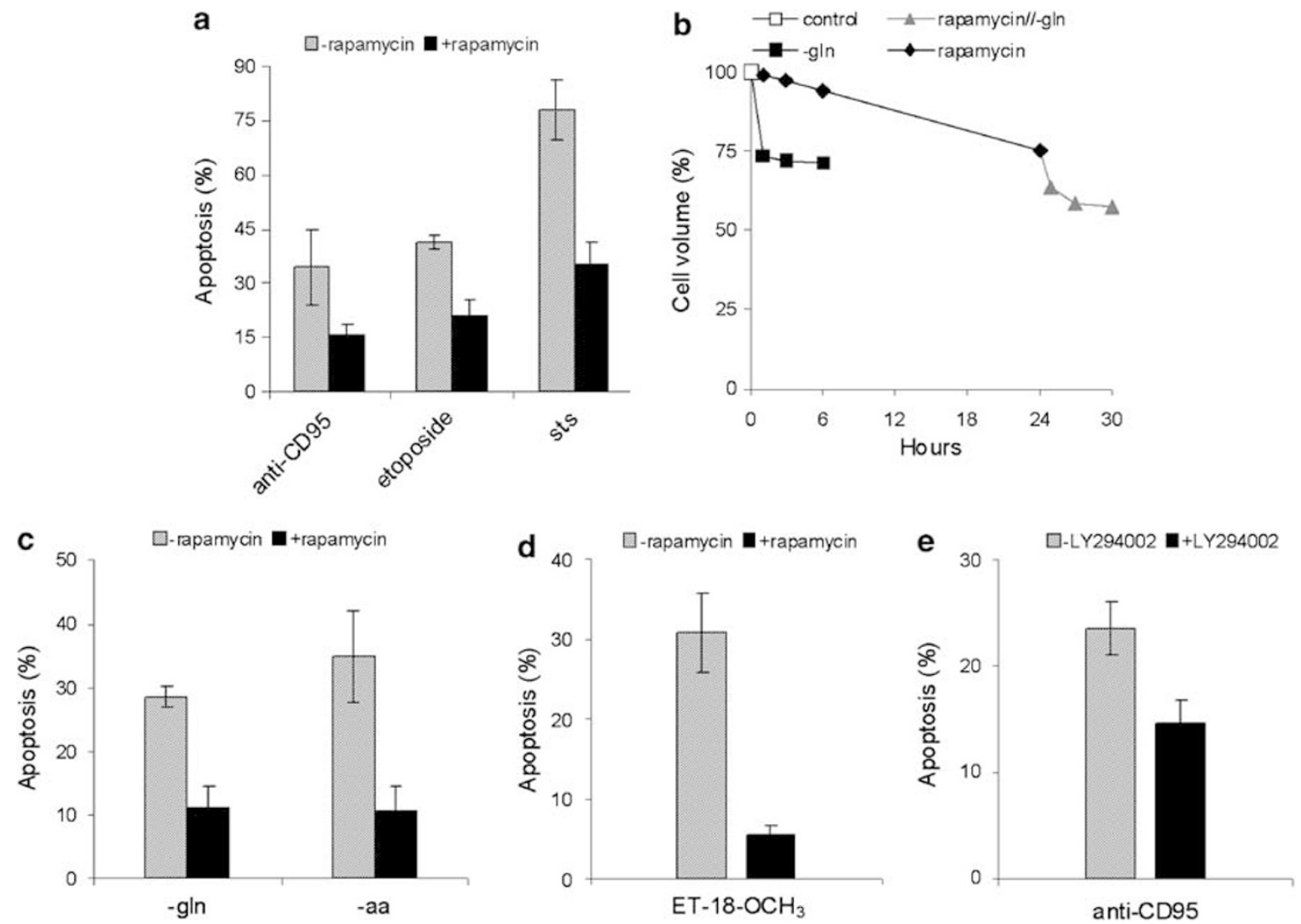

Figure 4 Small-size cells resulting from rapamycin- or LY294002-dependent deactivation of the mTOR/S6K pathway are protected from receptor-mediated and stressinduced cell death. (a) Jurkat cells, seeded at a density of $0.5 \times 10^{6} \mathrm{cells} / \mathrm{ml}$, were incubated in dialyzed FBS-supplemented RPMl 1640 in the absence $(-$ rapamycin, basal medium) or the presence of $20 \mathrm{nM}$ rapamycin. After $24 \mathrm{~h}$, the cells were transferred into basal medium at a density of $1 \times 10^{6} \mathrm{celll} / \mathrm{ml}$ and incubated for $6 \mathrm{~h}$ in the presence of $\mathrm{CH} 11$ anti-CD95 antibody $(0.1 \mu \mathrm{g} / \mathrm{ml})$, etoposide $(10 \mu \mathrm{M})$ or staurosporine (sts, $0.3 \mu \mathrm{M})$. Apoptosis was quantitated by fluorescence microscopy analysis on Hoechst 33342 and propidium iodide-stained cells. Data, expressed as percent values, are means \pm S.D. of three to six separate experiments. (b) Cells, seeded at a density of $0.5 \times 10^{6} \mathrm{cells} / \mathrm{ml}$, were incubated: (1) in basal medium for $24 \mathrm{~h}$ (control); (2) in dialyzed FBS-supplemented glutamine-free RPMl 1640 in the absence of rapamycin for $6 \mathrm{~h}(-\mathrm{gln}) ;(3)$ in the presence of $20 \mathrm{nM}$ rapamycin for $24 \mathrm{~h}$ (rapamycin) and then transferred into dialyzed FBS-supplemented glutamine-free RPMl 1640 in the absence of rapamycin (rapamycin//-gln), and incubated for an additional $6 \mathrm{~h}$. Cell water volumes were estimated at the indicated time intervals by transmembrane ${ }^{3} \mathrm{H}-\mathrm{OMG}$ distribution. Data, expressed as percent of the control values, are from a representative experiment. The experiment, repeated three times, yielded similar results. (c) Cells, incubated for $24 \mathrm{~h}$ with or without $20 \mathrm{nM}$ rapamycin as described in (a), were then transferred into glutamine-free medium (-gln) or into amino-acid-free medium (-aa) and incubated for $6 \mathrm{~h}$ (d) Cells were incubated for $24 \mathrm{~h}$ with or without $20 \mathrm{nM}$ rapamycin as described in (a) and then transferred into basal medium containing ET-18- $\mathrm{OCH}_{3}(5 \mu \mathrm{g} / \mathrm{ml})$, and incubated for $6 \mathrm{~h}$. In (c) and (d), apoptosis was quantitated as described in (a); data, expressed as percent values, are means + S.D. of three to six experiments. (e) Cells, seeded at a density of $0.5 \times 10^{6} \mathrm{celll} / \mathrm{ml}$, were incubated for $24 \mathrm{~h}$ in dialyzed FBS-supplemented RPMl 1640 in the absence (-LY294002) or the presence of $30 \mu \mathrm{M} \mathrm{LY} 294002$. The cells were then reseeded into basal medium at a density of $1 \times 10^{6}$ cells/ml and incubated for $6 \mathrm{~h}$ in the presence of $\mathrm{CH} 11$ anti-CD95 antibody $(0.1 \mu \mathrm{g} / \mathrm{ml})$. Apoptosis was quantitated as described in (a). Data, expressed as percent values, are means \pm S.D. of three experiments

tosis ${ }^{54}$ ). As shown in Figure $4 \mathrm{~b}$, Jurkat cells, induced to decrease their size by long-lasting pretreatment with rapamycin, when incubated in a glutamine-free medium underwent a further fast reduction of their volume, but this shrinkage was significantly less effective in promoting apoptosis than the shrinkage induced by glutamine deprivation in normal-size untreated cells (Figure 4c). A comparable protection from apoptosis in cells pretreated with rapamycin for $24 \mathrm{~h}$ was observed when the shrinkage was induced by amino-acid withdrawal (Figure 4c). Rapamycin-induced small-size Jurkat cells were also protected from ligand-independent CD95launched apoptosis induced by the ether lipid 1-O-octadecyl2-O-methyl-rac-glycero-3-phosphocholine $\left(\mathrm{ET}-18-\mathrm{OCH}_{3}\right)^{55,56}$ (Figure 4d). As reported above, a 24-h treatment of Jurkat cells with LY294002 at a marginally toxic concentration
$(30 \mu \mathrm{M})^{49}$ induced a decrease in cell size (cf. Figure 1b) accompanied by about $10 \%$ apoptosis in the cell population and these small-size cells were protected from cell death promoted by CD95 receptor-ligation with agonistic anti-CD95 antibodies (Figure 4e). A deactivation of the mTOR/S6K1 pathway by leucine deprivation was also associated with a progressive cell size decrease (Figure 1f). However, the cell population included a large fraction of dead cells (Figure 3a), presumably due to a cycle arrest-dependent proapoptotic effect of leucine depletion in constitutive c-myc expressing cells. $^{57,58}$ This preparation, as such or after a preliminary procedure to set the preparation free of dead cells, was illsuited to study whether leucine deprivation-induced smallsize cells were protected from apoptosis. In a large number of experiments (19) a significant protection from apoptosis 
induced by CD95 ligation with agonistic anti-CD95 antibodies occurred in more than half of them, but not in the remaining. The explanation is entirely unclear and more studies are needed to understand the basis for these apparently contradictory observations. We then asked whether a significant decrease in cell size caused by a rapamycin-dependent deactivation of the mTOR/S6K1 pathway was an unavoidable requirement for cell protection against apoptosis or whether
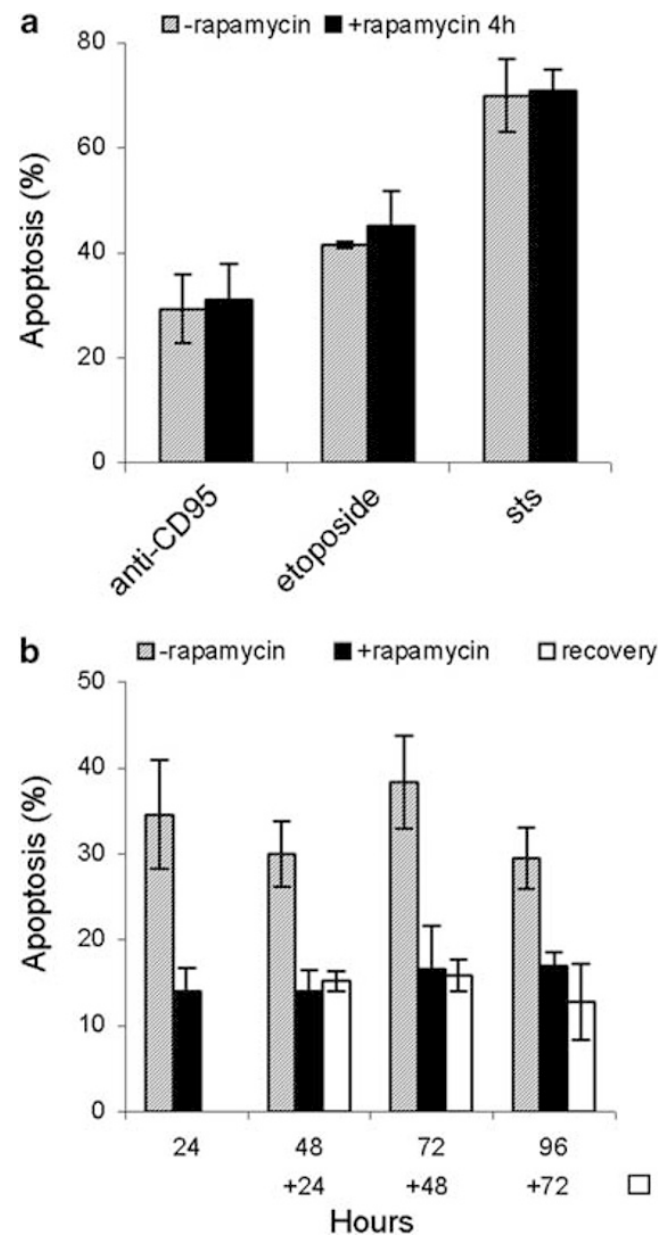

Figure 5 Cell size reduction, but not mTOR-deactivating rapamycin treatment per se, protects the cells against apoptosis. (a) Jurkat cells, seeded at a density of $0.5 \times 10^{6} \mathrm{cell} / \mathrm{s} / \mathrm{ml}$, were incubated for $4 \mathrm{~h}$ in dialyzed FBS-supplemented RPMl 1640 in the absence (-rapamycin) or the presence of $20 \mathrm{nM}$ rapamycin. The cells were then transferred into basal medium at a density of $1 \times 10^{6} \mathrm{cell} / \mathrm{s} / \mathrm{ml}$ and incubated for $6 \mathrm{~h}$ in the presence of $\mathrm{CH} 11$ anti-CD95 antibody $(0.1 \mu \mathrm{g} / \mathrm{ml})$, etoposide $(10 \mu \mathrm{M})$ or staurosporine (sts, $0.3 \mu \mathrm{M})$. Apoptosis was quantitated by fluorescence microscopy analysis on Hoechst 33342 and propidium iodidestained cells. Data, expressed as percent values, are means \pm S.D. of three to six experiments. (b) Jurkat cells, seeded at a density of $0.5 \times 10^{6} \mathrm{cell} / \mathrm{s} / \mathrm{ml}$, were incubated: (1) for $96 \mathrm{~h}$ in dialyzed FBS-supplemented RPMI 1640 (always renewed every $24 \mathrm{~h}$, with cell density restored at the same initial value by a splitting procedure) in the absence (-rapamycin, control) and the presence of $20 \mathrm{nM}$ rapamycin, newly added at every medium renewal along the entire incubation period or (2) in the presence of $20 \mathrm{nM}$ rapamycin for $24 \mathrm{~h}$ and then transferred into basal medium for an additional $72 \mathrm{~h}$ (recovery). At the indicated time intervals cells from each condition were reseeded into basal medium at a density of $1 \times 10^{6} \mathrm{cells} / \mathrm{ml}$ and incubated in the presence of $\mathrm{CH} 11$ anti-CD95 antibody $(0.1 \mu \mathrm{g} / \mathrm{ml})$ for $6 \mathrm{~h}$. Apoptosis was then quantitated as described in (a). Data, expressed as percent values, are means \pm S.D. of three experiments the rapamycin treatment inhibited the apoptotic death independently of its effect on cell growth rate and cell size reduction. In Jurkat cells, rapamycin treatment deactivates the mTOR/S6K1 pathway in less than $2 \mathrm{~h}^{9}{ }^{9}$ In $4 \mathrm{~h}$ lasting experiments, rapamycin treatment did not significantly affect Jurkat cell size (Figure 1d and cf. Fumarola et al. ${ }^{9}$ ) and, under these conditions, the treatment was completely ineffective in preventing cell death induced by CD95 receptor-ligation with agonistic anti-CD95 antibodies or by etoposide- or Stspromoted mitochondrial perturbation (Figure 5a). Moreover, we asked whether the protective effect against apoptosis in rapamycin-pretreated small-size cells persisted independently of a continuous presence of rapamycin in the incubation medium. In these experiments, Jurkat cells, incubated for $24 \mathrm{~h}$ in $20 \mathrm{nM}$ rapamycin-containing medium, were transferred into the basal medium (always renewed every $24 \mathrm{~h}$, with cell density restored at the same initial value by a splitting procedure) and incubated for additional $72 \mathrm{~h}$ (with a further final assay at $144 \mathrm{~h}$ of incubation). After rapamycin removal, the protection against apoptosis induced by CD95 receptor-ligation with agonistic anti-CD95 antibodies was effective for at least $72 \mathrm{~h}$ (Figure $5 \mathrm{~b}$ ) and vanished at $144 \mathrm{~h}$ (35\% in control versus $37 \%$ apoptosis in recovered cells, means of three experiments) when, after complete S6K1 rephosphorylation (Figure 1a), the cells recovered their initial mass. A comparable trend of persistent protection after rapamycin removal was also observed in rapamycin-pretreated cells induced to apoptose by Sts-promoted mitochondrial perturbation.

\section{Protection from apoptotic cell death at molecular level}

The decreased susceptibility to apoptosis associated to the cell size-reduction promoted by long-lasting deactivation of the mTOR/S6K pathway, as assessed by morphological observations, has been confirmed at the molecular level. The CD95 receptor-mediated apoptosis (extrinsic pathway) was monitored by Annexin V-FITC surface exposure, DNA fragmentation, procaspase- $8,-9$ and -3 cleavage and caspase-8, -9 and -3 activity. When normal-size (control) and small-size Jurkat cells (with rapamycin treatment used as prototypical cell mass-reduction procedure) were induced to apoptose by CD95 receptor-ligand interaction using the agonistic $\mathrm{CH} 11$ anti-CD95 antibody, the number of Annexin $\mathrm{V}$-positive cells (indicating phosphatidylserine exposure on the plasma membrane) at $3 \mathrm{~h}$ was about $50 \%$ of that detected in normal-size cells (means of three experiments). As assessed after additional 3h, DNA fragmentation was markedly reduced and cleavage of procaspase-8, -9 and -3 decreased significantly (without a change in their total protein expression) as did the catalytic activity of the proteolitically processed caspases (Figure 6). Similar results were obtained when the apoptotic pathway was launched by ligandindependent CD95 multimerization induced by glutamine deprivation. The apoptotic death pathway induced by Stspromoted mitochondrial perturbation (intrinsic pathway) was monitored by assessment of caspase-2 processing, mitochondrial transmembrane potential and permeabilization with 
release of cytochrome $c$ and apoptosis-inducing factor (AIF). Small-size Jurkat cells induced to apoptose by Sts, as compared to normal-size (control) cells, showed a greatly diminished cleavage of caspase-2 (without a change in total protein expression), a decreased permeabilization of the

a

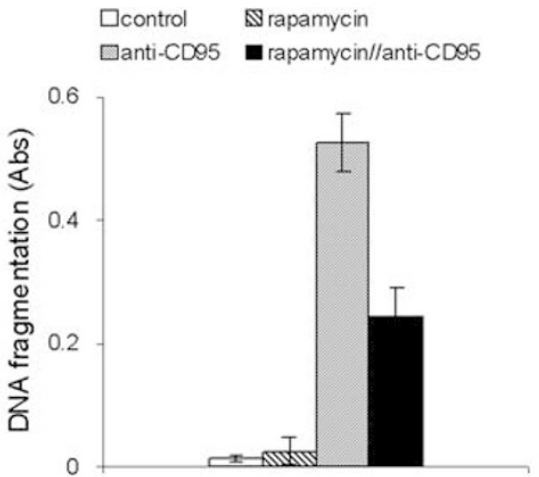

b

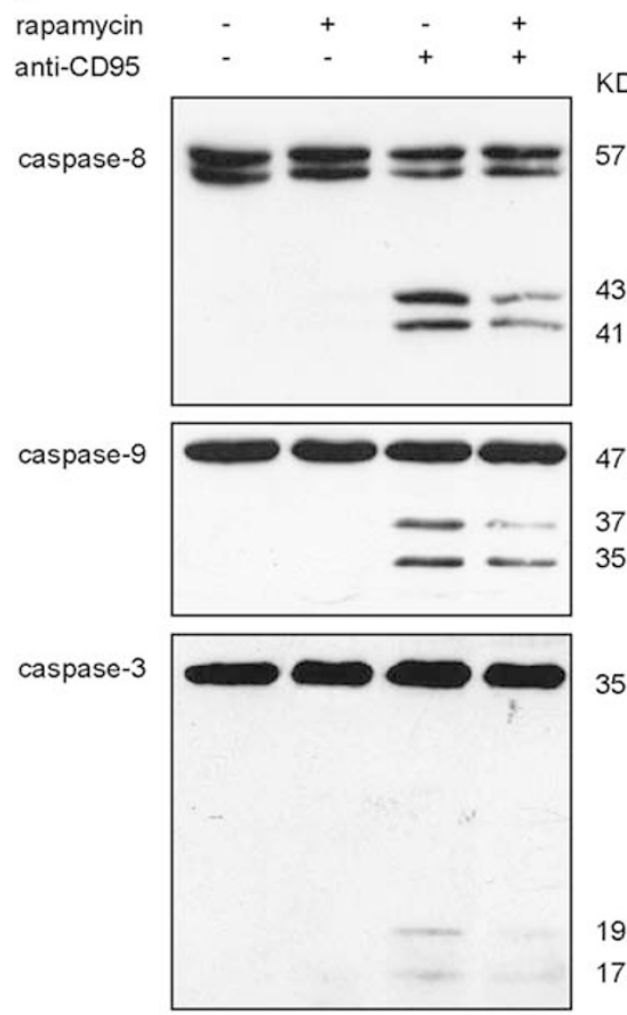

C

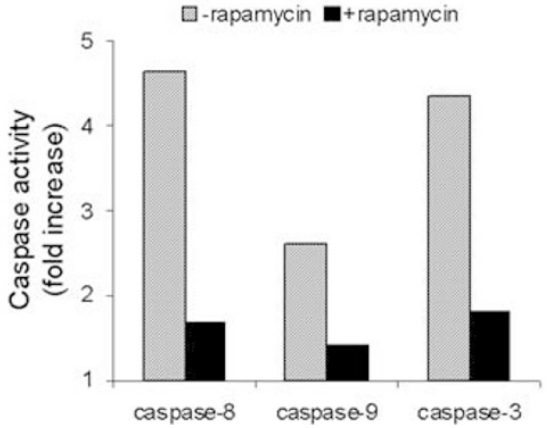

mitochondrial membrane, indirectly assessed by a lower dissipation in transmembrane potential $\left[\Delta \Psi_{\mathrm{m}}\right]$, and a reduced release of cytochrome $c$ and AIF into the cytosol (Figure 7). Similar results on dissipation in transmembrane potential and release of cytochrome $c$ were obtained when the intrinsic apoptotic pathway was induced by etoposide. Jurkat cells incubated in the presence of rapamycin in short-term experiments $(4 \mathrm{~h})$ did not change their volume appreciably (Figure 1d) and, when the apoptotic pathway was triggered by a CD95 receptor-ligand interaction, were responsive as untreated control cells without attenuation of DNA fragmentation, cleavage of procaspase $-8,-9$ and -3 or activity of caspase-8, -9 and -3 . Comparable short-term experiments showed that mitochondrial permeabilization or cytochrome $c$ release were not prevented in Jurkat cells when the mitochondrial apoptotic pathway was induced by Sts or etoposide.

\section{Cell-size reduction does not affect the expression of a number of apoptosis-involved gene products}

As assessed by Western blot analysis and specific antibodies, long-lasting rapamycin treatments inducing inactivation of the mTOR/S6K pathway in Jurkat cells did not appreciably affect the expression level of the following protein products: c-Myc, FADD, Bid, Bax, Bcl-2 and Bcl- $x_{\mathrm{L}}$ (Figure 8); moreover, in rapamycin-treated cells, protection from a $6 \mathrm{~h}$ CD95 receptorinduced apoptosis was not associated with changes in the expression of all these proteins (Figure 8). Cytofluorimetric analysis showed that the expression of CD95 receptors at the cell membrane did not change significantly (not shown).

\section{Discussion}

Long-lasting rapamycin treatments and leucine deprivation (representative of nutrient-poor conditions ${ }^{9}$ ) that deactivate the mTOR/S6K1 pathway promote a gradual, progressive, reduction of size in Jurkat cells. A cell size decrease occurs also when cells are treated with LY294002, an inhibitor of the $\mathrm{PI3K} / \mathrm{Akt} / \mathrm{mTOR}$ pathway that suppresses the activity of PI3K and mTOR at similar concentrations. ${ }^{59}$ Viable small-size cells generated by rapamycin treatment retain proliferation, although at a slow rate. Jurkat cells used in these experiments are distributed among the cycle phases. As shown in

Figure 6 The lower susceptibility of mTOR deactivation-dependent small-size cells to receptor-mediated apoptosis is indicated by a reduction in DNA fragmentation, a diminished procaspase cleavage, and a decreased catalytic activity of relevant caspases. Jurkat cells, seeded at a density of $0.5 \times 10^{6}$ cells/ $\mathrm{ml}$, were incubated in dialyzed FBS-supplemented RPMI 1640 in the absence (control) or in the presence of $20 \mathrm{nM}$ rapamycin. After $24 \mathrm{~h}$, the cells were transferred into basal medium at a density of $1 \times 10^{6} \mathrm{cells} / \mathrm{ml}$ and incubated for $6 \mathrm{~h}$ in the presence of $\mathrm{CH} 11$ anti-CD95 antibody $(0.1 \mu \mathrm{g} / \mathrm{ml})$. (a) DNA fragmentation was determined by photometric enzyme immunoassay; data are means \pm S.D. of three separate experiments; (b) cleavage of procaspase- $8,-9$ and -3 was assessed on lysate proteins by Western blotting. The migration position of each full length procaspase and of their processing products is indicated; (c) activity of caspase-8, -9 and -3 was measured on cell lysates by a colorimetric assay and data for anti-CD95 antibody-treated cells are shown as fold increase relative to the corresponding control. Data in $\mathbf{b}$ and $\mathbf{c}$ are from $\mathbf{a}$ representative experiment. The experiments, repeated at least three times, yielded similar results 
a

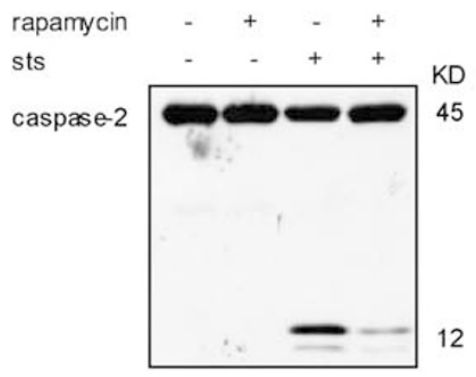

b

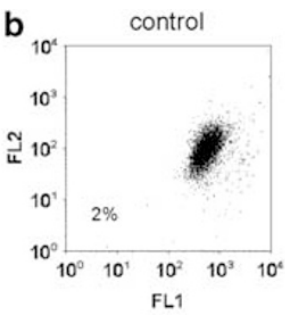

sts

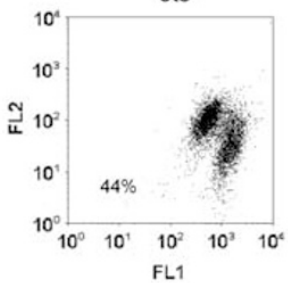

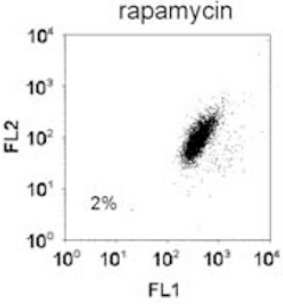

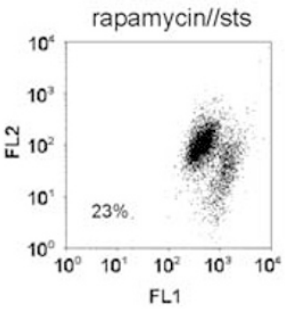

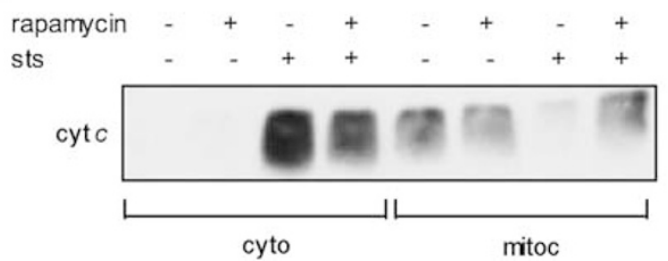

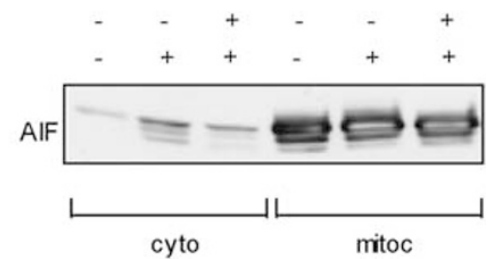

Figure 7 The lower susceptibility of mTOR deactivation-dependent small-size cells to mitochondrially-mediated cell death is indicated by a reduced cleavage of caspase-2, a lower dissipation of mitochondrial membrane potential and a decreased release of cytochorome $c$ and AIF from mitochondria. Jurkat cells, seeded at a density of $0.5 \times 10^{6} \mathrm{cell} / \mathrm{s} / \mathrm{ml}$, were incubated for $24 \mathrm{~h}$ in dialyzed FBS-supplemented RPMl 1640 in the absence (control) or the presence of $20 \mathrm{nM}$ rapamycin. The cells were then transferred into basal medium at a density of $1 \times 10^{6} \mathrm{cell} / \mathrm{ml}$ and incubated up to $6 \mathrm{~h}$ in the presence of staurosporine (sts, $0.3 \mu \mathrm{M}$ ). (a) Cleavage of caspase2 was determined after $3 \mathrm{~h}$ of incubation on lysate proteins by Western blotting. The migration position of full length caspase and of its processing products is indicated; (b) mitochondrial transmembrane potential was assessed after $3 \mathrm{~h}$ of incubation by flow cytometric analysis of cells stained with MitoCapture fluorochrome. Signals of fluorochrome monomers (green fluorescence) and aggregates (red fluorescence) were detected through the FL1 and FL2 channels, and bivariate plots of red versus green fluorescence signals are shown. A shift from red to green fluorescence denotes dissipation of mitochondrial membrane potential. The percentage of mitochondriadepolarized cells is indicated; (c) cytochrome $c$ and AIF release from mitochondria was assessed after $6 \mathrm{~h}$ of incubation by Western blotting analysis of cell cytosolic and mitochondrial fractions. Results presented in $\mathbf{a}, \mathbf{b}$ and $\mathbf{c}$ are from a representative experiment. Each experiment, repeated three times, yielded similar results

Figure $2 \mathrm{~b}$, a rapamycin treatment increases the relative number of cells residing in $\mathrm{G}_{1}$ phase but, upon rapamycin removal, the distribution of cells among the cycle phases reverts to normal earlier than resumption of a full proliferation rate (Figure 2a). Therefore, the decreased proliferation rate of rapamycin-treated small-size cells is not entirely dependent on their accumulation in $\mathrm{G}_{1}$ phase and possibly reflects a complex slowing down of the entire cell cycle. It has been proposed that an active mTOR/S6K1 pathway, and possibly S6 phosphorylation, by selectively promoting the translation of 5'-TOP mRNAs encoding ribosomal proteins, may contribute to prevent the increase of cell-cycle regulators until the cell has reached an appropriate size for division. ${ }^{43}$ In this view, the inhibition of the pathway by rapamycin with ribosomal protein mRNA no longer preferentially translated, could allow a cell-cycle regulator to accumulate relatively rapidly, resulting in cell division even at a small size. ${ }^{42,43}$ Some recent studies, ${ }^{60,61}$ however, have questioned the link between S6K1, S6 phosphorylation and 5'-TOP mRNA translation. Whatever the explanation, our results show that, under nutrient (leucine)-rich conditions, proliferation of rapamycintreated cells lasts for several days and decreases as a function of the length of the incubation period. This behavior may reflect a rapamycin-dependent perturbation of the mTOR function $^{20,22}$ at a site downstream of the amino-acid-TOR pathway. ${ }^{12}$ Indeed, it has been suggested that rapamycin perturbs the $\mathrm{G} \beta \mathrm{L}$-mediated raptor-mTOR interaction necessary for mTOR to form a nutrient-sensitive complex. ${ }^{20}$ In contrast, viable small-size cells resulting from leucine deprivation cease to divide. These cells, when transferred into a nutrient (leucine)-rich environment, resume proliferation at an increasing rate along the growth-dependent recovery of their size promoted by the amino-acid-dependent reactivation of the mTOR/S6K1 pathway.

In small-size cells resulting from a persistent deactivation of the mTOR/S6K pathway promoted by rapamycin (as prototypical cell mass-reduction procedure), we found that: (a) protection from CD95-receptor-mediated apoptosis involves diminished proteolytic cleavage of relevant procaspases-8, -9 and -3 and decreased activity of the resulting caspases; under these conditions the expression level of CD95 receptor at the cell surface, of FADD adaptor and of regulators such as Bid, $\mathrm{Bax}, \mathrm{Bcl}-2$, and $\mathrm{Bcl}-\mathrm{x}_{\mathrm{L}}$ does not change significantly and (b) protection from stressor-induced cell death is associated with impaired processing of caspase- 2 and enhanced resistance to permeabilization of the mitochondrial membrane with 


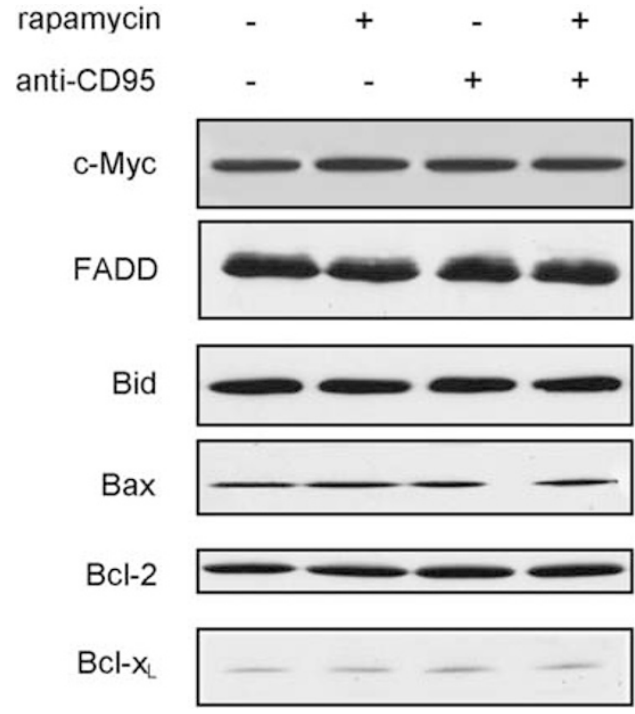

Figure 8 The expression of several gene products involved in apoptosis is not affected by the mTOR deactivation-dependent reduction of cell size. Jurkat cells, seeded at a density of $0.5 \times 10^{6} \mathrm{celll} / \mathrm{ml}$, were incubated in dialyzed FBSsupplemented RPMI 1640 in the absence (control) or the presence of $20 \mathrm{nM}$ rapamycin. After $24 \mathrm{~h}$, the cells were transferred into basal medium at a density of $1 \times 10^{6} \mathrm{cells} / \mathrm{ml}$ and incubated for $6 \mathrm{~h}$ in the presence of $\mathrm{CH} 11$ anti-CD95 antibody $(0.1 \mu \mathrm{g} / \mathrm{ml})$. Protein expression was assessed by Western blot analysis

reduced release of cytochrome $c$ and AIF (the reduced release of AIF suggests also a protection from caspaseindependent cell death ${ }^{62}$ ). In contrast, rapamycin treatments of short duration $(4 \mathrm{~h})$ that inhibit the mTOR/S6K1-signaling pathway for a period of time insufficient to reduce growth and mass of cells significantly do not protect them against the receptor/ligand interaction- or the stressor-induced apoptotic death, indicating that the drug is unable to restrain these deadly processes directly. Whether the decreased rate of cell division induced by long-lasting rapamycin treatments is at play during the generation or selection of small-size cells resistant to apoptosis remains an open question. We have shown that, in rapamycin-pretreated small-size cells, the protective effect against apoptosis persists along the period of recovery after rapamycin removal. In this period, the initial altered distribution of cells in the cycle phases (accumulation of cells in $G_{1}$ ) reverts to normal (Figure $2 b$ ), while cell volume and rate of cell proliferation are still below the control values (cf Figure $1 \mathrm{~b}$ and $2 \mathrm{a}$ ). Therefore, rapamycin treatments that reduce cell size are likely to promote protection from apoptosis through mechanisms that alter the small-size cell response in a skewed way, with delayed return to the unprotected condition. Perhaps, a hypothetical sensor could measure directly or indirectly some correlate to the decreased cellular mass so that, for some time, cells may become more resilient to lethal assaults by curbing the cell's suicidal response to this condition. Moreover, the decreased cell mass resulting from the defective growth may contribute to protect the cell from the inevitable cell death that would result from a reduced growth rate unable to keep up with a rapid rate of cell division. In our biological model, these protection mechanisms could be intended as an approach to survival. At the molecular level, we found that in small-size Jurkat cells several steps of death-signaling pathways (death receptorand mitochondrially-mediated ${ }^{63}$ ) are somehow hindered. In particular, cell size reduction is associated with a significant impairment of cleavage of the apical caspases involved in death receptor-induced apoptosis (caspase-8, Figure $6 \mathrm{~b}$ ) and in cellular stressor-promoted apoptosis (caspase-2, Figure 7a). In cells induced to apoptose by CD95 receptor ligation, the initial activation of caspase-8 is followed by its cleavage, with a significant part of the detectable processed caspase resulting from an amplification loop (caspase-8dependent proteolytic cleavage of the $\mathrm{BH} 3$-only protein Bid to tBid, mitochondrial permeabilization with cytochrome $C$ release by $\mathrm{tBid} / \mathrm{Bax}$ and activation of effector caspases). ${ }^{47,64,65} \mathrm{~A}$ decreased contribution of this loop to caspase-8-processing in small-size Jurkat cells (Figure 6b) cannot be excluded. In type II cells, the cleavage of caspase-2 may occur upstream of the mitochondrion, ${ }^{66}$ while a significant contribution to this processing by a mitochondrial feedback loop, largely attributed to the proteolytic activity of the effector caspase-3, has been reported. ${ }^{64,67}$ In our experiments, the lower dissipation in transmembrane potential $\left[\Delta \Psi_{\mathrm{m}}\right]$ and the reduced release of cytochrome $c$ observed in small-size Jurkat cells (Figure $7 \mathrm{~b}$ and c) do not discriminate between inhibition on caspase-2 processing (Figure 7a) upstream of the mitochondrion (affecting the initial caspase activation), or at the mitochondrial membrane (with hindrance at some level of the mitochondrial amplification loop). Recent data indicate that, in Jurkat cells, fully processed caspase-2 can directly permeabilize the outer mitochondrial membrane with release of cytochrome $c$ and smac/DIABLO (but not of AIF), an effect that appears to require processing of the zymogen, but not the associated catalytic activity. ${ }^{68,69}$ However, as shown in Figure 7c, Sts treatment, beside cytochrome $c$, promotes the release of AIF from Jurkat cell mitochondria. This finding suggests that either caspase-2 activation/processing can act in conjunction with Bax/Bak to release this death-inducing factor, ${ }^{69}$ or that other agents are involved in this effect. All these data lead us to speculate that the substantial reduction in cell size and mass might decrease membrane fluidity that, in turn, would restrain lateral diffusion of receptors at the plasma membrane and perhaps hamper permeabilization of mitochondrial membranes. Should a lateral diffusion of proteins in the plasma membrane be lowered in rapamycin treatment-dependent small-size Jurkat cells, it would restrict the CD95 receptors from forming functional multimers necessary to activate caspase-8 in ligand-dependent and ligand-independent activation of the apoptotic extrinsic pathway. Consistent with this view, the inhibition of lateral diffusion of CD95 in the plasma membrane of Th2 lymphocytes restrains the receptor multimerization and the subsequent caspase-8 cleavage to its catalytically active forms, with protection against apoptosis. ${ }^{70}$ Moreover, in Jurkat cells, the ligand-independent apoptosis induced by the ether lipid ET-18-OCH ${ }_{3}^{55}$ (translocation of CD95 into membrane lipid rafts, rafts clustering, CD95 multimerization, activation of initiator caspase-8 and recruitment of Bid linking CD95 receptor to mitochondrial-signaling routes ${ }^{56}$ ) is largely prevented in rapamycin treatment-dependent small-size Jurkat cells (Figure 4d), suggesting hampered diffusion of 
signaling molecules and/or delayed raft clustering in cell membranes.

Based on several preclinical research lines, the interest in mTOR as a potential target of inhibition in cancer therapy, and particularly in the hematologic malignancies, is deep and increasing. Inhibitors such as rapamycin and its derivatives sirolimus (CCL-779) and everolimus (designated rapamycins) restrain cell growth and proliferation of many tumor cell lines in culture. ${ }^{71}$ High sensitivity to rapamycins has been observed in PTEN-deficient brain, prostate, breast and multiple myeloma cells, with induction of $\mathrm{G}_{1}$ cell-cycle accumulation or arrest, ${ }^{72}$ sometimes followed by apoptosis (as in primary multiple myeloma cells ${ }^{73}$ ). However, a rapamycin-dependent induction of apoptosis have not been seen in other tumor cell lines including Jurkat, ${ }^{53}$ and we have shown that long-lasting rapamycin treatment protects Jurkat cells against apoptosis. Therefore the use of rapamycin, alone or as a sensitizer of other chemotherapeutic agents ${ }^{74}$ is only likely to work in malignancies that suppress apoptosis through the mTORdependent pathway. Tumors that rely on mTOR-independent antiapoptotic signals or that react to the rapamycin treatments with a cell size reduction-promoted antiapoptotic effect are expected to be unresponsive. In the latter tumors, the impact of rapamycins treatment may be reminiscent of p53 suppressor gene loss, which accelerates Myc-induced tumorigenesis by disabling apoptosis. ${ }^{75}$

\section{Materials and Methods}

\section{Cells and culture conditions}

Human T-lymphoblastoid Jurkat cells, purchased from American Type Culture Collection (Rockville, MD, USA), were maintained in RPMI 1640 supplement with $10 \%$ FBS, penicillin $(100 \mathrm{U} / \mathrm{ml})$, streptomycin $(100 \mu \mathrm{g} / \mathrm{ml})$ at $37^{\circ} \mathrm{C}$ in an atmosphere of $5 \% \mathrm{CO}_{2}$ in air. Cells were grown and used in suspension cultures, always split $24 \mathrm{~h}$ before the experiments. All experiments were made on subcultures $\left(0.5-1 \times 10^{6} \mathrm{cells} / \mathrm{ml}\right)$ incubated in RPMI 1640 (or modified/reconstituted RPMI) supplemented with $10 \%$ dialyzed FBS. Leucine- and glutamine-free RPMI were purchased and amino-acid-free RPMI was reconstituted from components (salts, glucose, vitamins, etc.) of RPMI, except amino acids.

\section{Dead cell removal}

Dead cells were positively separated by high-gradient magnetic sorting using the magnetic cell separator MiniMACS ${ }^{\mathrm{TM}}$ (Miltenyi Biotec, Bergisch Gladbach, Germany) according to the protocol provided by the manufacturer. Briefly, $10^{7}$ cells were resuspended in $100 \mu$ l of Dead Cell Removal MicroBeads and incubated for $15 \mathrm{~min}$ at room temperature. The $\mathrm{MS}^{+}$Separation Column was placed in the MiniMACS ${ }^{\mathrm{TM}}$ magnet and rinsed with the binding buffer. The cell suspension was applied onto the column that retained the positive cells and let the negative viable cells pass through. Effluent was collect as live cell fraction.

\section{Cell mass measurements}

Cell water volume was estimated by measurements of steady-state transmembrane distribution of 3-0-methyl-D-[1- $\left.{ }^{3} \mathrm{H}\right]$ glucose (OMG), as described previously. ${ }^{54}$ Briefly, labeled OMG was added during the last $40 \mathrm{~min}$ of incubation. The cells were then quickly washed twice in ice-cold
Earle's balanced salt solution and extracted in ice-cold 10\% trichloroacetic acid. Radioactivity was measured by liquid-scintillation counting with a Packard 460C spectrometer (Packard Bioscience BV, The Netherlands) in three to five independent experiments. Cell protein content was measured by Bradford assay ${ }^{76}$ and dry cell mass was estimated from the ratio of dry/ fresh weight measurements with a Chan electrobalance, as previously described. ${ }^{77}$

\section{ATP detection}

Cell content of ATP was determined by a luminescence assay system (ATPLite $^{\mathrm{TM}}$-M, Packard) as described previously. ${ }^{9}$ Fifty microliters of cell lysis solution was added to $100 \mu$ l of cell suspension $\left(4 \times 10^{4}\right.$ cells) per well of a 96 -well microplate. After shaking, $50 \mu \mathrm{l}$ of substrate solution (luciferin/luciferase) was added to each well. The plate was shaken and adapted in the dark. Luminescence was measured by the Packard TopCount Microplate Scintillation and Luminescence Counter. The unknown ATP concentrations were calculated on the basis of the ATPstandard curve. Each measurement value represents the mean of four single readings.

\section{Western blot analysis}

Jurkat cells were rinsed twice and solubilized in lysis buffer as described. ${ }^{9}$ $60-100 \mu \mathrm{g}$ protein of cell lysate was resolved by sodium, dodecyl sulfatepolyacrylamide gel electrophoresis (SDS-PAGE) and transferred to nitrocellulose membranes. The membranes were then incubated with (a) a 1:1000 dilution of the rabbit phosphospecific anti-p70 ${ }^{\mathrm{S6k}}\left(\mathrm{Thr}^{421}\right.$ $\mathrm{Ser}^{424}$ ) antibody; ${ }^{23,33}$ (b) a 1:1000 mouse anticaspase-8 antibody; (c) a $1: 1000$ rabbit anticaspase-9 antibody; (d) a 1:1000 rabbit anticaspase-3 antibody; (e) a 1:100 mouse anticaspase-2 antibody; (f) a 1:600 mouse anti-c-Myc antibody; (g) a 1:250 mouse anti-FADD antibody; (h) a $1: 1000$ rabbit anti-Bid antibody; (i) a $1: 100$ rabbit anti-Bax antibody; (j) a $1: 100$ mouse anti-Bcl-2 antibody; (k) a $1: 100$ mouse anti-Bcl- $x_{\mathrm{L}}$ antibody and (I) a 1:3000 mouse antiactin antibody. Cytosolic and mitochondrial fractions were generated from Jurkat cells using a digitonin-based subcellular fractionation technique. ${ }^{78}$ Equal volumes of cytosolic and mitochondrial fractions (corresponding to $80 \mu \mathrm{g}$ protein of the cytosolic fraction) were resolved by SDS-PAGE and transferred to nitrocellulose membranes. The membranes were then incubated with (a) a 1:300 mouse anticytochrome $c$ antibody and (b) a 1:400 mouse anti-AIF antibody. Blots were then washed and incubated with horseradish peroxidase (HRP)-anti-mouse or HRP-anti-rabbit antibodies at 1:20000 dilution. Immunoreactive bands were visualized by using an enhanced chemiluminescence system. The intensity of the bands corresponding to phosphospecific $\mathrm{p} 70^{\mathrm{S} 6 \mathrm{k}}$ protein was quantified by densitometric analysis (UN-SCAN-IT ${ }^{\mathrm{TM}}$ gel).

\section{Determination of proliferation rate and cell-cycle analysis}

Cell proliferation was evaluated by counting the cells in a Bürker hemocytometer and cell viability was assessed by trypan blue exclusion. Distribution of the cells in the cell cycle was determined by propidium iodide staining and flow cytometry analysis. Briefly, $5 \times 10^{5}$ cells were incubated overnight at $4^{\circ} \mathrm{C}$ in $1 \mathrm{ml}$ of hypotonic fluorochrome solution. Analysis was performed with Coulter EPICS XL-MCL cytometer (Coulter Co., Miami, FL, USA). Cell-cycle-phase distributions were analyzed by 
MultiCycle DNA Content and Cell Cycle Analysis Software (Phoenix Flow Systems, Inc., San Diego, CA, USA).

\section{Detection of apoptosis}

Apoptosis was assessed by (a) morphology on stained (Hoechst 33342 , propidium iodide) or unstained cells using light-, phasecontrast- and fluorescence-microscopy; (b) FITC-conjugated Annexin V assay (Bender MedSystems, Vienna, Austria); (c) DNA fragmentation by a photometric enzyme immunoassay (Cell Death Detection Elisa ${ }^{\text {PLUS }}$ Roche Diagnostic, Mannheim, Germany); (d) caspase-8, -9 and -3 activity by a colorimetric assay (MBL, Watertown, MA, USA); (e) caspase- $8,-2,-9$ and -3 cleavage and release of cytochrome $c$ and AIF by Western blotting procedure; ( $f$ ) dissipation of mitochondrial membrane potential by the MitoCapture ${ }^{\mathrm{TM}}$ Assay Kit (MBL) and flow cytometric analysis, as previously described. ${ }^{9}$

\section{Antibodies and reagents}

RPMI 1640 and FBS were purchased from Gibco-BRL (Grand Island, NY, USA). Leucine- and glutamine-free RPMI 1640 were from ICN Biomedicals, Inc. (Irvine, CA, USA). Polyclonal anti-p70 ${ }^{56 \mathrm{k}}\left(\mathrm{Thr}^{421}\right.$ / $\mathrm{Ser}^{424}$ ), polyclonal anti-Bax (P-19), monoclonal anti-Bcl-2 (C-2), monoclonal anti-BCl- $\mathrm{X}_{\mathrm{L}}(\mathrm{H}-5)$, monoclonal anticytochrome $c(7 \mathrm{H} 8)$ and monoclonal anti-AIF (E-1) antibodies were obtained from Santa Cruz Biotechnology (Santa Cruz, CA, USA). Monoclonal anticaspase-8 (1C12), polyclonal anticaspase-9, polyclonal anticaspase-3 and polyclonal anti-Bid antibodies were from Cell Signaling Technology (Beverly, MA, USA). Polyclonal anticaspase-2 antibody was from Chemicon International (Temecula, CA, USA). Monoclonal anti-c-Myc antibody was from Cambridge Research Biochemicals (Wilmington, DE, USA). Monoclonal anti-FADD antibody was from BD Biosciences (San Jose, CA, USA). Monoclonal antiactin (AC-40) antibody was from Sigma-Aldrich (St. Louis, MO, USA). HRP-conjugated secondary antibodies and the enhanced chemiluminescence system (ECL) were from Pierce (Rockford, IL, USA). Reagents for electrophoresis and blotting analysis were obtained from BIO-RAD Laboratories. Monoclonal anti-CD95 $\operatorname{lgM}(\mathrm{CH}-11)$ antibody was from MBL. 3-o-methyl-D-[1- $\left.{ }^{3} \mathrm{H}\right]$ glucose was purchased from Amersham Pharmacia Biotech (Buckinghamshire, UK). Rapamycin, LY294002, Sts, etoposide, ET-18- $\mathrm{OCH}_{3}$ and other reagents were from Sigma-Aldrich.

\section{Acknowledgements}

This work was supported by a FIL grant from MIUR (Rome, Italy) and by Associazione Chiara Tassoni (Parma, Italy). We thank Dr. Marta Chiarini for technical support.

\section{References}

1. Shmelzle T and Hall MN (2000) TOR, a central controller of cell growth. Cell 103: 253-262

2. Shamji AF, Nghiem $P$ and Schreiber SL (2003) Integration of growth factor and nutrient signalling: implications for cancer biology. Mol. Cell 12: 271-280

3. Fingar DC and Blenis J (2004) Target of rapamycin (TOR): an integrator of nutrient and growth factor signals and coordinator of cell growth and cell cycle progression. Oncogene 23: 3151-3171

4. Avruch J, Belham C, Weng Q, Hara K and Yonezawa K (2001) The p70 S6 kinase integrates nutrient and growth signals to control translational capacity. Prog. Mol. Subcell. Biol. 26: 115-154
5. Liu XM, Reyna SV, Ensenat D, Peyton KJ, Wang H, Schafer Al and Durante W (2004) Platelet-derived growth factor stimulates LAT1 gene expression in vascular smooth muscle: role in cell growth. FASEB J. 18: 768-770

6. Jefferson LS and Kimball SR (2003) Amino acids as regulators of gene expression at the level of mRNA translation. J. Nutr. 133: 2046S2051S

7. Meijer AJ (2003) Amino acids as regulators and components of nonproteinogenic pathways J. Nutr. 133: 2057S-2062S

8. Edinger AL and Thomson CB (2002) Akt maintains cell size and survival by increasing mTOR-dependent nutrient uptake. Mol. Biol. Cell 13: 2276-2288

9. Fumarola C, La Monica S and Guidotti GG (2005) Amino acid signaling through the mammalian target of rapamycin (mTOR) pathway: role of glutamine and of cell shrinkage. J. Cell. Physiol. 204: 155-165

10. Hara K, Yonezawa K, Weng Q-P, Kozlowski MT, Belham C and Avruch $J$ (1998) Amino acid sufficiency and mTOR regulate p70 S6 Kinase and elF-4E BP1 through a common effector mechanism. J. Biol. Chem. 273: 14484-14494

11. Christie GR, Hajduch E, Hundal HS, Proud CG and Taylor PM (2002) Intracellular sensing of amino acids in Xenopus laevis oocytes stimulates p70 S6 kinase in a target of rapamycin-dependent manner. J. Biol. Chem. 277; 9952-9957

12. Gao X, Zhang Y, Azzarola P, Hino O, Kobayashi T, Yeung RS, Ru B and Pan D (2002) Tsc tumour suppressor proteins antagonize amino-acid-TOR signalling. Nat. Cell Biol. 4: 699-704

13. Beugnet A, Tee AR, Taylor PM and Proud CG (2003) Regulation of targets of mTOR (mammalian target of rapamycin) signalling by intracellular amino acid availability. Biochem. J. 372: 555-566

14. Dennis PB, Jaeschke A, Saitoh M, Fowler B, Kozma SC and Thomas G (2001) Mammalian TOR: a homeostatic ATP sensor. Science 294: 1102-1105

15. Desai BN, Myers BR and Schreiber SL (2002) FKBP12-rapamycin-associated protein associates with mitochondria and senses osmotic stress via mitochondrial dysfunction. Proc. Natl. Acad. Sci. USA 99: 4319-4324

16. Bolster DR, Crozier SJ, Kimball SR and Jefferson LS (2002) AMP-activated protein kinase suppresses protein synthesis in rat skeletal muscle through down-regulated mammalian target of rapamycin (mTOR) signaling. J. Biol. Chem. 277: 23977-23980

17. Conlon I and Raff M (1999) Size control in animal development. Cell 96: 235244

18. Brown EJ, Albers MW, Shin TB, Ichikawa K, Keith CT, Lane WS and Schreiber SL (1994) A mammalian protein targeted by G1-arresting rapamycin-receptor complex. Nature 369: 756-758

19. Sabatini DM, Erdjument-Bromage H, Lui M, Tempst $P$ and Snyder SH (1994) RAFT1: a mammalian protein that binds to FKBP12 in a rapamycin dependent fashion and is homologous to yeast TORs. Cell 78: 35-43

20. Kim D-H, Sarbassov DD, Ali SM, King JE, Latek RR, Erdjument-Bromage $H$, Tempst $P$ and Sabatini DM (2002) mTOR interacts with raptor to form a nutrient-sensitive complex that signals to the cell growth machinery. Cell 110 : $163-175$

21. Hara K, Maruki $Y$, Long $X$, Yoshino K, Oshiro N, Hidayat S, Tokunaga C, Avruch $\mathrm{J}$ and Yonezawa K (2002) Raptor, a binding partner of target of rapamycin (TOR), mediates TOR action. Cell 110: 177-189

22. Kim D-H, Sarbassov DD, Ali SM, Latek RR, Guntur KVP, Erdjument-Bromage $H$, Tempst $P$ and Sabatini DM (2003) $G \beta L$, a positive regulator of the rapamycin-sensitive pathway required for the nutrient-sensitive interaction between raptor and mTOR. Mol. Cell 11: 895-904

23. Khaleghpour K, Pyronnet, Gingras AC and Sonenberg N (1999) Translational homeostasis: eukaryotic translation initiation factor $4 \mathrm{E}$ control of $4 \mathrm{E}$-binding protein 1 and p70 S6 kinase activities. Mol. Cell Biol. 19: 4302-4310

24. Gingras AC, Raught B and Sonenberg N (2001) Regulation of translation initiation by FRAP/mTOR. Genes Dev. 15: 807-826

25. Montagne J, Stewart MJ, Stocker H, Hafen E, Kozma SC and Thomas G (1999) Drosophila S6 kinase: a regulator of cell size. Science 285: 21262129

26. Oldham S, Montagne J, Radimerski T, Thomas G and Hafen E (2000) Genetic and biochemical characterization of dTOR, the Drosophila homolog of the target of rapamycin. Genes Dev. 14: 2689-2694

27. Zhang H, Stallock JP, Ng JC, Reinhard C and Neufeld TP (2000) Regulation of cellular growth by the Drosophila target of rapamycin dTOR. Genes Dev. 14: 2712-2724 
28. liboshi $Y$, Papst PJ, Kawasome $\mathrm{H}$, Hosoi $\mathrm{H}$, Abraham RT, Houghton PJ and Terada N (1999) Amino acid-dependent control of p $70^{s 6 \mathrm{k}}$. Involvement of tRNA aminoacylation in the regulation. J. Biol. Chem. 274: 1092-1099

29. Fingar DC, Salama S, Tsou C, Harlow E and Blenis J (2002) Mammalian cell size is controlled by mTOR and its downstream targets S6K1 and 4EBP1/ elF4E. Genes Dev. 16: 1472-1487

30. Edinger AL, Linardic CM, Chiang GG, Thompson CB and Abraham RT (2003) Differential effects of rapamycin on mammalian target of rapamycin signalling functions in mammalian cells. Cancer Res. 63: 8451-8460

31. Burnett PE, Barrow RK, Cohen NA, Snyder SH and Sabatini DM (1998) RAFT1 phosphorylation of the translational regulators p70 S6 kinase and 4E-BP1. Proc. Natl. Acad. Sci. USA 95: 1432-1437

32. Templeton DJ (2001) Protein kinases: getting NEKed for S6K activation. Curr. Biol. 11: R596-R599

33. Le XF, Hittelman WN, Liu J, McWatters A, Li C, Mills GB and Bast Jr RC (2003) Paclitaxel induces inactivation of p70 S6 kinase and phosphorylation of $\mathrm{Th}^{421}$ and $\mathrm{Ser}^{424}$ via multiple signaling pathways in mitosis. Oncogene 22: 484-497

34. Pearson RB, Dennis PB, Han JW, Williamson NA, Kozma SC, Wettenhall RE and Thomas G (1995) The principal target of rapamycin-induced p70S6k inactivation is a novel phosphorylation site within a conserved hydrophobic domain. EMBO J. 14: 5279-5287

35. Murata K, Wu J and Brautigan DL (1997) B cell receptor-associated protein $\alpha 4$ displays rapamycin-sensitive binding directly to the catalytic subunit of protein phosphatase 2A. Proc. Natl. Acad. Sci. USA 94: 10624-10629

36. Nanahoshi M, Nishiuma T, Tsujishita Y, Hara K, Inui S, Sakaguchi N and Yonezawa K (1998) Regulation of protein phosphatase 2 A catalytic activity by alpha4 protein and its yeast homolog Tap42. Biochem. Biophys. Res. Commun. 251: 520-526

37. Goldberg Y (1999) Protein phosphatase 2A: who shall regulate the regulator? Biochem. Pharmacol. 57: 321-328

38. Peterson RT, Desai BN, Hardwick JS and Schreiber SL (1999) Protein phosphatase $2 \mathrm{~A}$ interacts with the $70-\mathrm{kDa}$ S6 kinase and is activated by inhibition of FKBP12-rapamycin-associated protein. Proc. Natl. Acad. Sci. USA 96: 4438-4442

39. Inui S, Sanjo H, Maeda K, Yamamoto H, Miyamoto E and Sakaguchi N (1998) Ig receptor binding protein 1 (alpha4) is associated with a rapamycin-sensitive signal transduction in lymphocytes through direct binding to the catalytic subunit of protein phosphatase 2A. Blood 92: 539-546

40. Parrott LA and Templeton DJ (1999) Osmotic stress inhibits p70/85 S6 kinase through activation of a protein phosphatase. J. Biol. Chem. 274: 24731-24736

41. Kloeker S, Reed R, McConnel JL, Chang D, Tran K, Westphal RS, Law BK, Colbran RJ, Kamoun M, Campbell KS and Wadzinski BE (2003) Parallel purification of three catalytic subunits of the protein serine/threonine phosphatase $2 \mathrm{~A}$ family $\left(\mathrm{PP}_{\mathrm{c}} \mathrm{A}_{c}, \mathrm{PP} 4_{c}\right.$, and $\left.\mathrm{PP} 6_{c}\right)$ and analysis of the interaction of PP2 $A_{c}$ with alpha4 protein. Protein Expr. Purif. 31: 19-33

42. Stocker $\mathrm{H}$ and Hafen E (2000) Genetic control of cell size. Curr. Opin. Genet. Dev. 10: $529-535$

43. Thomas $G$ (2000) An encore for ribosome biogenesis in the control of cell proliferation. Nat Cell Biol. 2: E71-E72

44. Algeciras-Schimnich A, Pietras EM, Barnhart BC, Legembre P, Vijayan S, Holbeck SL and Peter ME (2003) Two CD95 tumor classes with different sensitivities to antitumor drugs. Proc. Natl. Acad. Sci. USA 100: 11445-11450

45. Friesen C, Herr I, Krammer PH and Debatin KM (1996) Involvement of the CD95 (APO-1/FAS) receptor/ligand system in drug-induced apoptosis in leukemia cells. Nat. Med. 2: $574-577$

46. Krammer PH (1999) CD95(APO-1/Fas)-mediated apoptosis: live and let die. Adv. Immunol. 71: 163-210

47. Budihardjo I, Oliver H, Lutter M and Wang X (1999) Biochemical pathways of caspase activation during apoptosis. Annu. Rev. Cell Dev. Biol. 15: 269-290

48. Schmitz I, Kirchhoff S and Krammer PH (2000) Regulation of death receptormediated apoptosis pathways. Int. J. Biochem. Cell Biol. 32: 1123-1136

49. Rahmani M, Yu C, Reese E, Ahmed W, Hirsch K, Dent P and Grant S (2003) Inhibition of PI-3 kinase sensitizes human leukemic cells to histone deacetylase inhibitor-mediated apoptosis through p44/42 MAP kinase inactivation and abrogation of $\mathrm{p} 21$ (CIP1/WAF1) induction rather than AKT inhibition. Oncogene 18: 6231-6242
50. Gribble FM, Loussouarn G, Tucker SJ, Zhao C, Nichols CG and Ashcroft FM (2000) A novel method for measurement of submembrane ATP concentration. J. Biol. Chem. 275: 30046-30049

51. Makowska A, Zablocki K and Duszyński J (2000) The role of mitochondria in the regulation of calcium influx into Jurkat cells. Eur. J. Biochem. 267: 877-884

52. Kennedy HJ, Pouli AE, Ainscow EK, Jouaville LS, Rizzuto R and Rutter GA (1999) Glucose generates sub-plasma membrane ATP microdomains in single islet $\beta$-cells. J. Biol. Chem. 274: 13281-13291

53. Strauss G, Osen W and Debatin KM (2002) Induction of apoptosis and modulation of activation and effector function in T cells by immunosuppressive drugs. Clin. Exp. Immunol. 128: 255-266

54. Fumarola C, Zerbini A and Guidotti GG (2001) Glutamine deprivation-mediated cell shrinkage induces ligand-independent CD95 receptor signaling and apoptosis. Cell Death Differ. 8: 1004-1013

55. Gajate $\mathrm{C}$ and e Mollinedo $\mathrm{F}$ (2001) The antitumor ether lipid ET-18- $\mathrm{OCH}_{3}$ induces apoptosis through translocation and capping of Fas/CD95 into membrane rafts in human leukemic cells. Blood 98: 3860-3863

56. Gajate C, del Canto-Jañez E, Acuña U, Amat-Guerri F, Geijo E, Santos-Beneit AM, Veldman RJ and Mollinedo $F$ (2004) Intracellular triggering of Fas aggregation and recruitment of apoptotic molecules into Fas-enriched rafts in selective tumor cell apoptosis. J. Exp. Med. 200: 353-365

57. Askew DS, Ashmun R, Simmons BC and Cleveland JL (1991) Constitutive cmyc expression in an IL-3-dependent myeloid cell line suppresses cycle arrest and accelerates apoptosis. Oncogene 6: 1915-1922

58. Evan GI, Wyllie AH, Gilbert CS, Littlewood TD, Land H, Brooks M, Waters CM, Penn LZ and Hancock DC (1992) Induction of apoptosis in fibroblasts by c-myc protein. Cell 69: 119-128

59. Brunn GJ, Williams J, Sabers C, Wiederrecht G, Lawrence Jr JC and Abraham RT (1996) Direct inhibition of the signaling functions of the mammalian target of rapamycin by the phosphoinositide-3-kinase inhibitors wortmannin and LY294002. EMBO J. 15: 5256-5267

60. Tang H, Hornstein E, Stolovich M, Levy G, Livingstone M, Templeton D, Avruch $\mathrm{J}$ and Meyuhas $\mathrm{O}$ (2001) Amino acid-induced translation of TOP mRNA is fully dependent on phosphatidylinositol 3-kinase-mediated signaling, is partially inhibited by rapamycin, and is independent of S6K1 and rpS6 phosphorylation. Mol. Cell. Biol. 21: 8671-8683

61. Stolovich M, Tang H, Hornstein E, Levy G, Cohen R, Bae SS, Birnbaum MJ and Meyuhas $O$ (2002) Transduction of growth or mitogenic signals into translational activation of TOP MRNA is fully reliant on the phosphatidylinositol 3-kinase-mediated pathway but requires neither S6K1 nor rpS6 phosphorylation. Mol. Cell. Biol. 22: 8101-8113

62. Candé C, Cohen I, Daugas E, Ravagnan L, Larochette N, Zampami N and Kroemer G (2002) Apoptosis-inducing factor (AIF): a novel caspaseindependent death effector released from mitochondria. Biochimie 84 : 215-222

63. Fumarola C and Guidotti GG (2004) Stress-induced apoptosis: toward a symmetry with receptor-mediated cell death. Apoptosis 9: 77-82

64. Slee EA, Harte MT, Kluck RM, Wolf BB, Casiano CA, Newmeyer DD, Wang H-G, Reed JC, Nicholson DW, Alnemri ES, Green DR and Martin SJ (1999) Ordering the cytochrome $c$-initiated caspase cascade: hierarchical activation of caspases-2, -3, -6, -7, -8 and -10 in a caspase-9-dependent manner. J. Cell Biol. 144: 281-292

65. Sun X-M, Bratton SB, Butterworth M, MacFarlane M and Cohen GM (2002) Bcl2 and $\mathrm{BCl}-\mathrm{X}_{\mathrm{L}}$ inhibit $\mathrm{CD} 95$-mediated apoptosis by preventing mitochondrial release of Smac/DIABLO and subsequent inactivation of X-linked inhibitor-ofapoptosis protein. J. Biol. Chem. 277: 11345-11351

66. Wagner KW, Engels IH and Deveraux QL (2004) Caspase-2 can function upstream of Bid cleavage in the TRAIL apoptosis pathway. J. Biol. Chem. 279: 35047-35052

67. Baliga BC, Read SH and Kumar S (2004) The biochemical mechanism of caspase-2 activation. Cell Death Diff. 11: 1234-1241

68. Robertson JD, Gogvadze V, Kropotov A, Vakifahmetoglu H, Zhivotovsky B and Orrenius S (2004) Processed caspase-2 can induce mitochondria-mediated apoptosis independently of its enzymatic acticity. EMBO Rep. 5: 643-648

69. Enoksson M, Robertson JD, Gogvadze V, Bu P, Kropotov A, Zhivotovsky B and Orrenius S (2004) Caspase-2 permeabilizes the outer mitochondrial membrane and disrupts the binding of cytochrome $c$ to anionic phospholipds. J. Biol. Chem. 279: 49575-49578 
70. Varadhachary AS, Edidin M, Hanlon AM, Petr ME, Krammer PH and Salgame $P$ (2001) Phosphatidylinositol $3^{\prime}$-kinase blocks CD95 aggregation and caspase8 cleavage at the death-inducing signaling complex by modulating lateral diffusion of CD95. J. Immunol. 166: 6564-6569

71. Panwalkar A, Verstovsek S and Giles FJ (2004) Mammalian target of rapamycin inhibition as therapy for hematologic malignancies. Cancer 100: 657-666

72. Huang S and Houghton PJ (2003) Targeting mTOR signaling for cancer therapy. Curr. Opin. Pharmacol. 3: 371-377

73. Strömberg T, Dimberg A, Hammarberg A, Carlson K, Österborg A, Nilsson $\mathrm{K}$ and Jernberg-Wiklund $\mathrm{H}$ (2004) Rapamycin sensitizes multiple myeloma cells to apoptosis induced by dexamethasone. Blood 103 3138-3147
74. Wendel H-G, de Stanchina E, Fridman JS, Malina A, Ray S, Kogan S, CordonCardo C, Pelletier J and Lowe SW (2004) Survival signalling by Akt and elF4E in oncogenesis and cancer therapy. Nature 428: 332-337

75. Schmitt CA, Fridman JS, Yang M, Baranov E, Hoffman RM and Lowe SW (2002) Dissecting p53 tumor suppressor functions in vivo. Cancer Cell 1: 289-298

76. Bradford M (1976) A rapid and sensitive method for the quantitation of microgram quantities of protein utilizing the principle of protein-dye binding. Anal. Biochem. 72: 248-254

77. Guidotti GG, Lüneburgh B and Borghetti AF (1969) Amino acid uptake in isolated chick embryo heart cells. Biochem. J. 114: 97-105

78. Adrain C, Creagh EM and Martin SJ (2001) Apoptosis-associated release of Smac/DIABLO from mitochondria requires active caspases and is blocked by Bcl-2. EMBO J. 20: 6627-6636 